Prepared in cooperation with the Kansas Water Office, the Kansas Department of Health and Environment, The Nature Conservancy, the City of Lawrence, the City of Manhattan, the City of Olathe, the City of Topeka, and Johnson County WaterOne

\title{
Linear Regression Model Documentation and Updates for Computing Water-Quality Constituent Concentrations or Densities using Continuous Real-Time Water-Quality Data for the Kansas River, Kansas, July 2012 through September 2019
}

Open-File Report 2021-1018 



\section{Linear Regression Model Documentation and Updates for Computing Water-Quality Constituent Concentrations or Densities using Continuous Real-Time Water-Quality Data for the Kansas River, Kansas, July 2012 through September 2019}

By Thomas J. Williams

Prepared in cooperation with the Kansas Water Office, the Kansas Department of Health and Environment, The Nature Conservancy, the City of Lawrence, the City of Manhattan, the City of Olathe, the City of Topeka, and Johnson County WaterOne

Open-File Report 2021-1018 


\section{U.S. Geological Survey, Reston, Virginia: 2021}

For more information on the USGS - the Federal source for science about the Earth, its natural and living resources, natural hazards, and the environment—visit https://www.usgs.gov or call 1-888-ASK-USGS.

For an overview of USGS information products, including maps, imagery, and publications, visit https://store.usgs.gov/.

Any use of trade, firm, or product names is for descriptive purposes only and does not imply endorsement by the U.S. Government.

Although this information product, for the most part, is in the public domain, it also may contain copyrighted materials as noted in the text. Permission to reproduce copyrighted items must be secured from the copyright owner.

Suggested citation:

Williams, T.J., 2021, Linear regression model documentation and updates for computing water-quality constituent concentrations or densities using continuous real-time water-quality data for the Kansas River, Kansas, July 2012 through September 2019: U.S. Geological Survey Open-File Report 2021-1018, 18 p., https://doi.org/10.3133/ ofr20211018.

Associated data for this publication: U.S. Geological Survey, 2020, USGS water data for the Nation: U.S. Geological Survey National Water Information System database, https://doi.org/10.5066/F7P55KJN.

ISSN 2331-1258 (online) 


\section{Acknowledgments}

The author thanks the Kansas Water Office, the Kansas Department of Health and Environment, The Nature Conservancy, the City of Lawrence, the City of Manhattan, the City of Olathe, the City of Topeka, and Johnson County WaterOne for a beneficial and lasting partnership in monitoring water-quality conditions in the Kansas River.

The author thanks U.S. Geological Survey technical reviewers Teresa Rasmussen (Lawrence, Kansas), Kyle Juracek (Lawrence, Kans.), Mandy Stone (Lawrence, Kans.), and Heather Krempa (Lee's Summit, Missouri) for reviewing previous drafts of this report. The author also thanks U.S. Geological Survey geographer Diana Restrepo-Osorio for assistance in adjusting the study area map to fit the needs of this report. Lastly, this report would not have been possible without the hard work by past and present U.S. Geological Survey staff at the Kansas Water Science Center that assisted with data collection, analyses, and project and database management. 



\section{Contents}

Acknowledgments ……...................................................................................................................

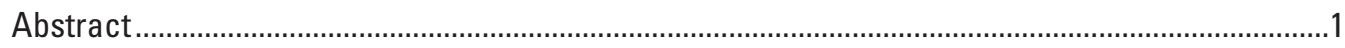

Introduction

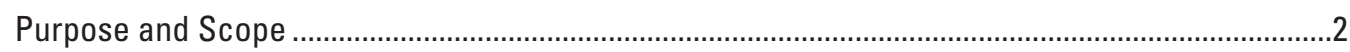

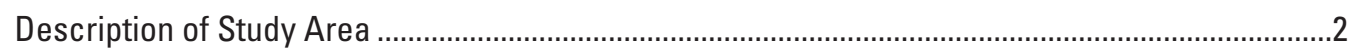

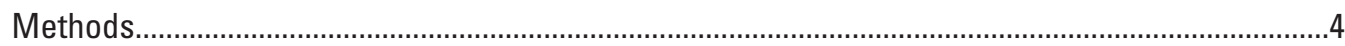

Continuous Streamflow and Water-Quality Monitoring ........................................................

Discrete Water-Quality Sampling................................................................................................

Quality Assurance and Quality Control of Continuous and Discrete Water-Quality Data .........5

Development and Update of Regression Models...............................................................

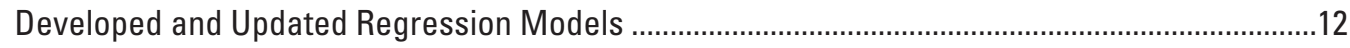

Total Dissolved Solids, Major lons, and Hardness ................................................................13

Nitrate Plus Nitrite, Total Nitrogen, Total Phosphorus, and Chlorophyll a ...............................13

Total Suspended Solids and Suspended Sediment.................................................................14

Fecal Indic ator Bacteria ................................................................................................

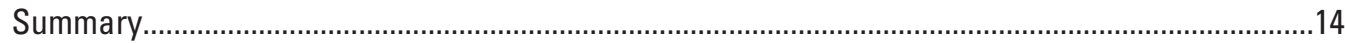

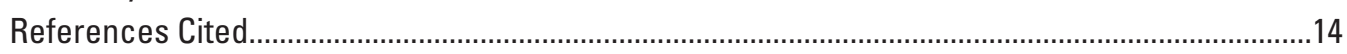

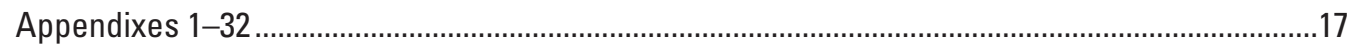

\section{Figures}

1. Map showing location of the Kansas River at Wamego and Kansas River at De Soto streamgages and discrete water-quality sampling sites in the lower Kansas River Basin, Kansas

2. Graph showing streamflow duration curves and discrete water-quality samples at the Kansas River at Wamego and Kansas River at De Soto, Kansas, streamgages during July 2012 through September 2019

\section{Table}

1. Linear regression models and summary statistics for computations of continuous water-quality constituent concentrations or densities for the Kansas River at Wamego and Kansas River at De Soto, Kansas, streamgages using data collected during July 2012 through September 2019. 


\section{Conversion Factors}

U.S. customary units to International System of Units

\begin{tabular}{lcl}
\hline \multicolumn{1}{c}{ Multiply } & \multicolumn{1}{c}{ By } & \multicolumn{1}{c}{ To obtain } \\
\hline & Length & \\
\hline foot $(\mathrm{ft})$ & 0.3048 & meter $(\mathrm{m})$ \\
mile $(\mathrm{mi})$ & 1.609 & kilometer $(\mathrm{km})$ \\
\hline & Area & \\
\hline square mile $\left(\mathrm{mi}^{2}\right)$ & 259.0 & hectare $(\mathrm{ha})$ \\
square mile $\left(\mathrm{mi}^{2}\right)$ & 2.590 & square kilometer $\left(\mathrm{km}^{2}\right)$ \\
\hline & Flow rate & \\
\hline cubic foot per second $(\mathrm{ft} 3 / \mathrm{s})$ & 0.02832 & cubic meter per second $\left(\mathrm{m}^{3} / \mathrm{s}\right)$ \\
\hline
\end{tabular}

International System of Units to U.S. customary units

\begin{tabular}{lcl}
\hline \multicolumn{1}{c}{ Multiply } & \multicolumn{1}{c}{ By } & \multicolumn{1}{c}{ To obtain } \\
\hline & Length & \\
\hline centimeter $(\mathrm{cm})$ & 0.3937 & inch (in.) \\
millimeter $(\mathrm{mm})$ & 0.03937 & inch (in.) \\
\hline & Volume & \\
\hline milliliter $(\mathrm{mL})$ & 0.0338 & ounce, fluid (fl. oz) \\
liter $(\mathrm{L})$ & 33.81402 & ounce, fluid (fl. oz) \\
\hline & Mass & \\
\hline milligram $(\mathrm{mg})$ & 0.00003527 & ounce, avoirdupois $(\mathrm{oz})$ \\
microgram $(\mu \mathrm{g})$ & 0.00000003527 & ounce, avoirdupois $(\mathrm{oz})$ \\
\hline
\end{tabular}

Temperature in degrees Celsius $\left({ }^{\circ} \mathrm{C}\right)$ may be converted to degrees Fahrenheit $\left({ }^{\circ} \mathrm{F}\right)$ as follows:

${ }^{\circ} \mathrm{F}=\left(1.8 \times{ }^{\circ} \mathrm{C}\right)+32$.

\section{Datum}

Horizontal coordinate information is referenced to the North American Datum of 1983 (NAD 83).

\section{Supplemental Information}

Specific conductance is given in microsiemens per centimeter at 25 degrees Celsius ( $\mu \mathrm{S} / \mathrm{cm}$ at $\left.25^{\circ} \mathrm{C}\right)$.

Concentrations of chemical constituents in water are given in either milligrams per liter (mg/L) or micrograms per liter ( $\mu \mathrm{g} / \mathrm{L})$.

Densities of fecal indicator bacteria are given in colonies per 100 milliliters (colonies/100 mL). 


\section{Abbreviations}

$\begin{array}{ll}\text { E. coli } & \text { Escherichia coli } \\ \text { KSWSC } & \text { Kansas Water Science Center } \\ \text { log } & \text { logarithm with base } 10 \\ \mathrm{MRL} & \text { minimum reporting limit } \\ \mathrm{NO}_{\mathrm{x}} & \text { nitrate plus nitrite } \\ \mathrm{NWQL} & \text { National Water Quality Laboratory } \\ p & \text { probability } \\ \text { PRESS } & \text { prediction error sum of squares } \\ \text { OA/OC } & \text { quality-assurance and quality-control } \\ R^{2} & \text { coefficient of determination } \\ \text { RMSE } & \text { root mean square error } \\ \text { RPD } & \text { relative percentage difference } \\ \text { USGS } & \text { U.S. Geological Survey } \\ \text { VIF } & \text { variance inflation factor }\end{array}$





\title{
Linear Regression Model Documentation and Updates for Computing Water-Quality Constituent Concentrations or Densities using Continuous Real-Time Water-Quality Data for the Kansas River, Kansas, July 2012 through September 2019
}

\author{
By Thomas J. Williams
}

\begin{abstract}
The Kansas River provides drinking water to about 800,000 people in northeastern Kansas. Water-treatment facilities that use the Kansas River as a water-supply source use chemical and physical processes during water treatment to remove contaminants before public distribution. Advanced notification of changing water-quality conditions near watersupply intakes allows water-treatment facilities to proactively adjust treatment. The U.S. Geological Survey (USGS), in cooperation with the Kansas Water Office (funded in part through the Kansas Water Plan), the Kansas Department of Health and Environment, The Nature Conservancy, the City of Lawrence, the City of Manhattan, the City of Olathe, the City of Topeka, and Johnson County WaterOne, collected water-quality data at the Kansas River at Wamego (USGS site 06887500; hereafter referred to as the "Wamego site") and De Soto (USGS site 06892350; hereafter referred to as the "De Soto site") monitoring sites to update previously published regression models relating continuous water-quality sensor measurements, streamflow, and seasonal components to discretely sampled water-quality constituent concentrations or densities. Linear regression analysis was used to update and develop models for total dissolved solids, major ions, hardness as calcium carbonate, nutrients (nitrogen and phosphorus species), chlorophyll $a$, total suspended solids, suspended sediment, and fecal indicator bacteria at the Wamego and De Soto monitoring sites using data collected during July 2012 through September 2019. The water-quality information documented in this report can be used as guidance for water-treatment processes and to characterize changes in water-quality conditions in the Kansas River over time that would not be otherwise possible.
\end{abstract}

\section{Introduction}

The Kansas River supplies drinking water to about 800,000 people in northeastern Kansas (Joan Kenny, U.S. Geological Survey, written commun., March 27, 2011). Additional uses of the Kansas River include recreation, aquatic-life support, food procurement, groundwater recharge, irrigation, and livestock water use (Kansas Department of Health and Environment, 2011). Water-treatment facilities that use the Kansas River as a drinking-water source use various chemical and physical processes to remove contaminants before distribution. Source-water quality affects treatment processes used to effectively remove contaminants. An advanced notification system of changing water-quality conditions, particularly those near water-supply intakes, provides watertreatment facilities the ability to proactively treat their water supply. Additionally, water-quality monitoring allows characterization of water-quality conditions in the Kansas River over time.

Concomitant Kansas River continuous water-quality monitoring and discrete water-quality sampling began during July 1999 (lasting through September 2005) with the primary goals of characterizing water-quality conditions and developing continuous regression-computed concentrations or densities of major ions, nutrients, sediment, fecal indicator bacteria, and trace elements using continuously measured water-quality properties as surrogates at sites near Wamego, Topeka, and De Soto, Kansas (Rasmussen and others, 2005). After water releases from Milford Lake (a reservoir that contributes streamflow to the Kansas River) during a toxic cyanobacterial bloom in August 2011, water-quality sampling resumed with the primary goal of characterizing cyanotoxin transport and associated taste-and-odor compounds from upstream reservoirs to the Kansas River (Graham and others, 2012). After this event, continuous and discrete water-quality monitoring continued at the Kansas River at Wamego (U.S. Geological Survey [USGS] site 06887500; hereafter referred to as the 
"Wamego site") and De Soto (USGS site 06892350; hereafter referred to as the "De Soto site") to describe water-quality conditions with an emphasis on cyanobacteria and associated toxins and taste-and-odor compounds and to develop a realtime notification system for changing water-quality conditions that may affect drinking-water-treatment processes (Foster and Graham, 2016; Graham and others, 2018). Foster and Graham (2016) developed continuous linear regression models that established relations between continuous and discrete waterquality data and provided real-time computations of constituent concentrations or densities for major ions, nutrients, sediment, and fecal indicator bacteria. Additionally, logistic regression models were developed that continuously computed the probability of cyanobacteria, microcystin (a cyanotoxin), and geosmin (a taste-and-odor compound) exceeding selected thresholds of interest (Foster and Graham, 2016). Foster and Graham (2016) developed new regression models using data collected during July 2012 through June 2015 at the Kansas River at Wamego and De Soto because of updated analytical methods and sensor technology, potential changes in drainage basin practices, water-quality conditions, riverine processes, and elapsed time between previously published models by Rasmussen and others (2005). The USGS, in cooperation with the Kansas Water Office (funded in part through the Kansas Water Plan), the Kansas Department of Health and Environment, The Nature Conservancy, the City of Lawrence, the City of Manhattan, the City of Olathe, the City of Topeka, and Johnson County WaterOne, continued water-quality data collection at the Wamego and De Soto sites to update previously published regression models developed by Foster and Graham (2016) and provide advanced notification of changing water-quality conditions for constituents of interest in the Kansas River. Real-time computations of water-quality constituent concentrations or densities using the models documented in this report are available at the USGS National Real-Time Water-Quality website (https://nrtwq.usgs.gov).

\section{Purpose and Scope}

The purpose of this report is to update previously published linear regression models (Foster and Graham, 2016) that continuously compute water-quality constituent concentrations or densities that are not easily measured in near-real time. This includes model updates for major ions, nutrients, sediment, and fecal indicator bacteria at the Wamego and De Soto sites (Foster and Graham, 2016). Additional water-quality data collected during July 2012 through September 2019 were used to develop new linear regression models, including hardness as calcium carbonate $\left(\mathrm{CaCO}_{3}\right)$, chlorophyll $a$, and total suspended solids; nitrate plus nitrite $\left(\mathrm{NO}_{\mathrm{x}}\right)$ and total phosphorus at the De Soto site; and Escherichia coli (E. coli), fecal coliform, and enterococci bacteria at the Wamego site. Linear regression models documented in this report characterize changes in water-quality conditions at the Wamego and
De Soto sites, which may affect drinking-water-treatment processes. The regression-computed concentrations or densities from these models are useful for comparison to Federal and State water-quality criteria, for computation of loads and yields to evaluate constituent transport through the drainage basin, and for characterization of changes in water-quality conditions in the Kansas River through time.

Logistic regression models that continuously computed the probability of occurrence above selected thresholds for cyanobacteria, microcystin, and geosmin developed by Foster and Graham (2016) were evaluated by Graham and others (2018) and generally did not fulfill the model suitability criteria. Additional data collected during cyanobacteria, microcystin, and geosmin events are necessary for future model refinement (Graham and others, 2018). Further logistic regression model evaluation is beyond the scope of this report.

\section{Description of Study Area}

The Kansas River Basin includes most of the northern half of Kansas, as well as parts of Nebraska and Colorado, and has an area of about 60,097 square miles (mi2; fig. 1). Formed by the confluence of the Smoky Hill and Republican Rivers near Junction City, Kans., the Kansas River flows about 174 miles east into the Missouri River at Kansas City, Kans. (fig. 1). The study area, commonly referred to as the lower Kansas River Basin, has an area of about 5,448 $\mathrm{mi}^{2}$ and consists of the area downstream from the confluence of the Smoky Hill and Republican Rivers. Four large reservoirs regulate streamflow in the Kansas River: Milford Lake, Tuttle Creek Lake, Perry Lake, and Clinton Lake (fig. 1). These bottom-release reservoirs were constructed during the 1960s and 1970s for flood control, recreation, and public water supply (U.S. Army Corps of Engineers, 2017). Although most of the study area is used for agricultural purposes (about 77 percent), urban areas represent about 9 percent of study area land use (Fry and others, 2011). There are four major urban areas along the Kansas River: Manhattan, Topeka, Lawrence, and Kansas City metropolitan area, Kans. (fig. 1). These cities and numerous smaller municipalities withdraw water from the Kansas River and its alluvial aquifer for public water supply. Rasmussen and others (2005), Graham and others (2012, 2018), and Foster and Graham (2016) describe the study area in greater detail.

Linear regression models that continuously compute water-quality constituent concentrations or densities were updated or developed at two sites along the Kansas River: the Wamego site and the De Soto site (fig. 1). The Wamego site is upstream from the four major public water-treatment facilities in the cities of Topeka, Lawrence, and Olathe and Johnson County WaterOne (fig. 1). The De Soto site is about 98 river miles downstream from the Wamego site and is upstream from the Johnson County WaterOne public water-treatment facility (fig. 1). 


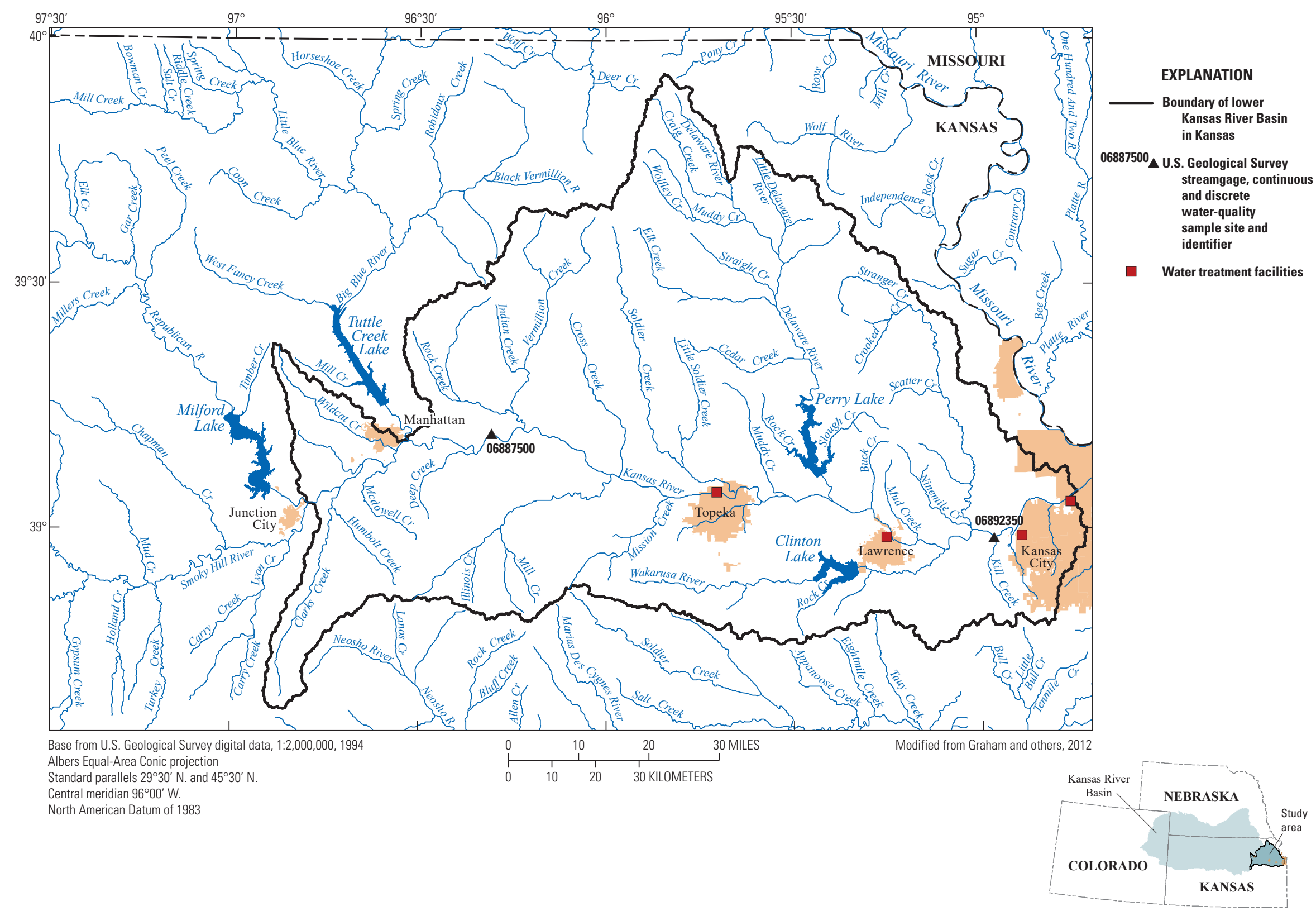

Figure 1. Location of the Kansas River at Wamego and Kansas River at De Soto streamgages and discrete water-quality sampling sites in the lower Kansas River Basin (U.S. Geological Survey sites 06887500 and 06892350, respectively), Kansas. 


\section{Methods}

Continuous and discrete water-quality data were collected at the Wamego and De Soto sites during July 2012 through September 2019. Data collected by the USGS over the range of streamflows at these sites during the study period (fig. 2) were used to update previously published site-specific linear regression models developed by Foster and Graham (2016) and to develop new site-specific linear regression models for several additional constituents because of additional samples collected during the current study period.

\section{Continuous Streamflow and Water-Quality Monitoring}

Streamflow data have been collected at the Wamego and De Soto sites since January 1919 and July 1917, respectively (U.S. Geological Survey, 2020). Continuous (15-minute interval) streamflow data during July 2012 through September 2019 were collected using standard USGS methods (Sauer and Turnipseed, 2010; Turnipseed and Sauer, 2010) and are available in near-real time (hourly) from the USGS National Water Information System database at https://doi.org/ 10.5066/F7P55KJN.

Continuous (15-minute interval) water-quality data collection at the Wamego and De Soto sites began during July 1999 through September 2004 and resumed in August and July 2012, respectively. During July 2012 through September 2019, water-quality monitors were suspended from bridges near the centroid of flow, about 1 to 3 feet below the water surface. Continuous water-quality monitors were operated and maintained in accordance with standard USGS methods (Wagner and others, 2006; Bennett and others, 2014). All data are available in near-real time (hourly) from the USGS National Water Information System database at https://doi.org/ 10.5066/F7P55KJN.

During July 2012 through June 2014, YSI 6600 V2 water-quality monitors were installed at each site and measured water temperature, specific conductance, $\mathrm{pH}$, dissolved oxygen, turbidity, and chlorophyll fluorescence. These monitors were replaced with YSI EXO2 water-quality monitors in June 2014 and measured the same properties as the YSI 6600 V2 in addition to phycocyanin fluorescence. All data recorded by the two monitor types were comparable during the study period (Foster and Graham, 2016) except for turbidity (YSI Incorporated, 2012) and chlorophyll fluorescence (Graham and others, 2018); because of this, the YSI 6600 V2 turbidity and chlorophyll fluorescence data were not included in model development for this report.

An optical $\mathrm{NO}_{\mathrm{x}}$ sensor (Hach Nitratax plus sc, 5-millimeter pathlength) was installed at the De Soto site during June 2013 through September 2019 alongside the EXO2 continuous water-quality monitor and was operated and maintained in accordance with USGS methods (Pellerin and others, 2013).

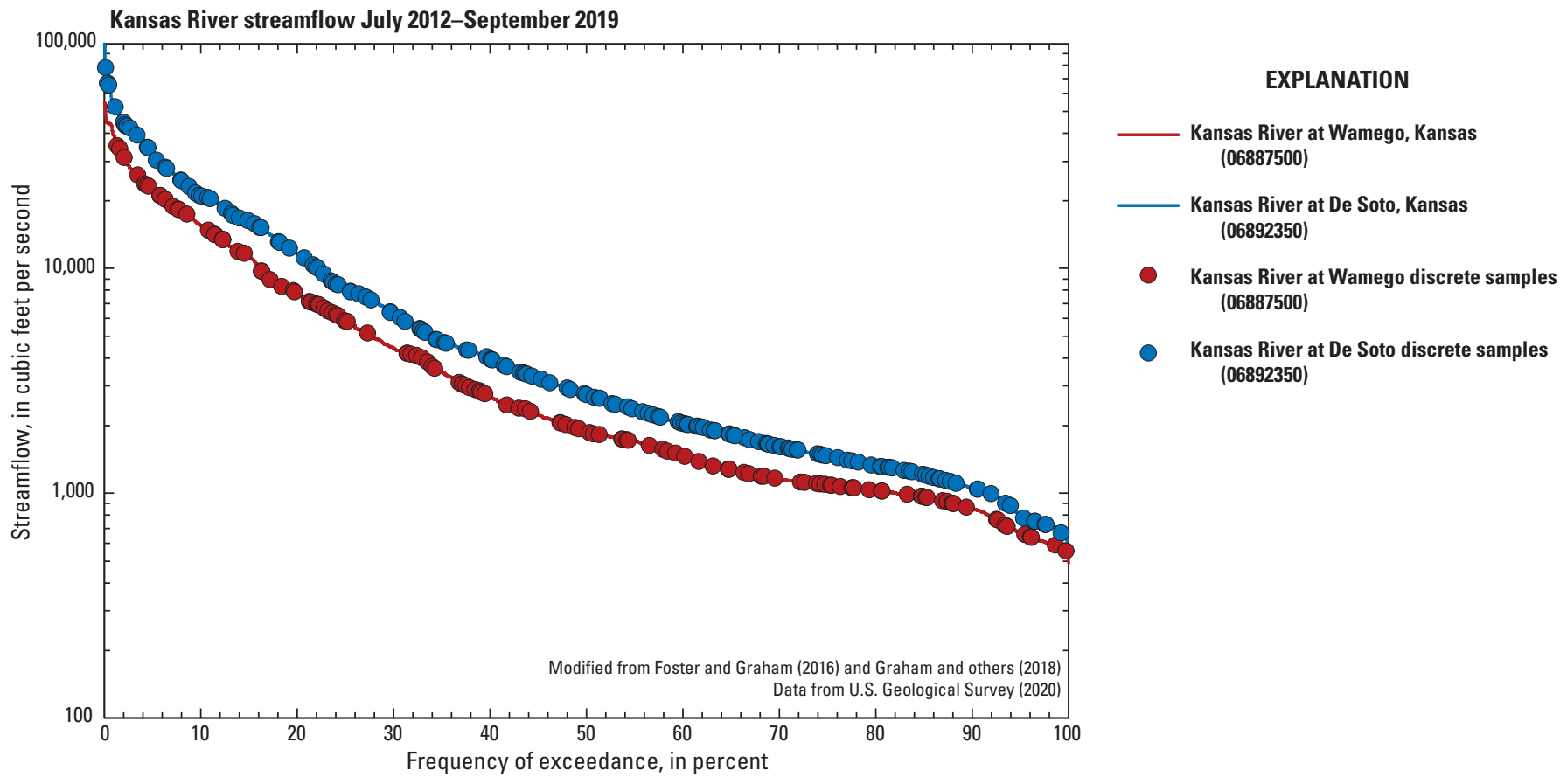

Figure 2. Streamflow duration curves and discrete water-quality samples at the Kansas River at Wamego and Kansas River at De Soto, Kansas, streamgages (U.S. Geological Survey sites 06887500 and 06892350, respectively) during July 2012 through September 2019. 


\section{Discrete Water-Quality Sampling}

During July 2012 through June 2017, water-quality samples at the Wamego and De Soto sites were collected biweekly during March through October, monthly during November through February, and during selected reservoir release and runoff events. During July 2017 through September 2019, water-quality samples at these sites were collected on a monthly to bimonthly basis, depending on flow conditions. Water-quality samples were collected over the range of flow conditions throughout the study period using this fixedschedule sampling approach (fig. 2). Water-quality samples were collected using depth- and width-integrated sampling techniques (U.S. Geological Survey, 2006). Occasionally, water-quality samples were collected using a weighted-basket or grab-sample approach (U.S. Geological Survey, 2006) near the centroid of flow or safest possible near-shore location for safety purposes during ice or extreme cold conditions. All fecal indicator bacteria samples were collected at the centroid of flow using a weighted basket. Water-quality samples were analyzed for dissolved solids, major ions, hardness as calcium carbonate, nutrients (nitrogen and phosphorus species), chlorophyll $a$ (indicator of algal biomass), suspended solids, suspended sediment, and fecal indicator bacteria (E. coli, fecal coliform, and enterococci). Because of a temporary project scope reduction, dissolved solids, major ions, hardness as calcium carbonate, suspended solids, and fecal indicator bacteria were not collected during August 2017 through September 2018.

Major ions (including dissolved solids and hardness as calcium carbonate), nutrients, turbidity, and suspended solids were analyzed at the USGS National Water Quality Laboratory (NWQL) in Lakewood, Colorado, following methods described in Fishman and Friedman (1989). Fecal indicator bacteria were analyzed at the USGS Kansas Water Science Center (KSWSC) following standard methods (U.S. Geological Survey, 2008). Suspended-sediment concentration was analyzed at the USGS Iowa Sediment Laboratory in Iowa City, Iowa, following standard methods (Guy, 1969). During July 2012 through June 2018, chlorophyll $a$ concentration was analyzed fluorometrically using U.S. Environmental Protection Agency Method 445.0 (Arar and Collins, 1997), modified for heated ethanol extraction (Sartory and Grobbelaar, 1984) using a fluorometer flow-through cell (Knowlton, 1984) at the USGS KSWSC. During June 2017 through September 2019, chlorophyll $a$ was analyzed at the USGS NWQL in Lakewood, Colo., using U.S. Environmental Protection Agency Method 445.0 (Arar and Collins, 1997).

Water-quality samples also were analyzed for phytoplankton abundance and community composition, microcystin (a cyanotoxin), and geosmin and 2-methylisoborneol (tasteand-odor compounds). As previously discussed, results of these analytes will not be used in this report because additional data collected during cyanobacteria, microcystin, and taste-and-odor events are necessary for future model refinement (Graham and others, 2018). Foster and Graham (2016) and Graham and others (2018) describe discrete water-quality sampling and analytical methodology for these constituents in greater detail.

\section{Quality Assurance and Quality Control of Continuous and Discrete Water-Quality Data}

All continuous and discrete water-quality data were reviewed and approved on a quarterly basis during the study period following guidance and the policies described by the USGS (U.S. Geological Survey, 2016, 2017). Continuous water-quality data occasionally had to be corrected because of fouling and sensor calibration drift (Wagner and others, 2006; Pellerin and others, 2013; Bennett and others, 2014) during August 2012 through September 2019. Additionally, continuous water-quality data were occasionally deleted or missing because of excessive fouling, equipment malfunction, or temporary removal to prevent equipment damage or loss during icy conditions. At the Wamego site during July 2012 through September 2019, about 6 percent of the water temperature and dissolved oxygen records, 7 percent of the $\mathrm{pH}$ record, 8 percent of the chlorophyll fluorescence record, 9 percent of the turbidity record, 10 percent of the specific conductance record, and 18 percent of the phycocyanin fluorescence record were missing or deleted. At the De Soto site during July 2012 through September 2019, about 7 percent of the water temperature record, 8 percent of the $\mathrm{pH}$ record, 9 percent of the dissolved oxygen record, 13 percent of the turbidity and chlorophyll fluorescence records, 15 percent of the specific conductance record, 19 percent of the phycocyanin fluorescence record, and 21 percent of the optical $\mathrm{NO}_{\mathrm{x}}$ record were missing or deleted. Missing continuous water-quality data were not estimated to fill in resultant data gaps.

Quality-assurance and quality-control (QA/QC) samples were collected during about 10 percent of all discrete waterquality sample collections. QA/QC samples collected throughout the study period included concurrent replicates and field and equipment blank samples. Concurrent replicate samples were collected to assess variability potentially introduced by sample collection and processing techniques, and by analytical method (Bennett and others, 2014; Mueller and others, 2015). Relative percentage difference (RPD) was used to quantify differences in noncensored constituent concentrations or densities among concurrent replicate pairs. The RPD was calculated by dividing the absolute difference of two replicate samples by their mean value and multiplying by 100 (Zar, 1999). Median RPDs among concurrent replicate pairs were considered acceptable if they were less than 5 percent for total dissolved solids, major ions, and hardness as calcium carbonate; less than 10 percent for nutrients (nitrogen and phosphorus species), chlorophyll $a$, total suspended solids, and suspended-sediment concentration; and less than 30 percent for fecal indicator bacteria. A total of 26 concurrent replicate pairs were collected at the Wamego and De Soto sites during July 2012 through September 2019. Median RPDs among 
concurrent replicate pairs for total dissolved solids, major ions, and hardness as calcium carbonate were 1.29, 0.67, and 0.73 percent, respectively. Median RPDs for nutrients (nitrogen and phosphorus species) and chlorophyll $a$ were 2.29 and 6.55 percent, respectively. Median RPDs for total suspended solids and suspended-sediment concentration were 6.35 and 6.05 percent, respectively. Fecal indicator bacteria had greater variability among concurrent replicate pairs, having a median RPD of 22.9 percent. Insufficient sample mixing when processing fecal indicator bacteria samples can increase variability among replicate paired samples (Myers and others, 2014). Overall, concurrent replicate QA/QC objectives were met for all constituents used for model development as described in this report.

Split-replicate samples were collected to assess analytical variability among laboratories and methodology for chlorophyll $a$ analysis by the USGS KSWSC (analyzed chlorophyll $a$ during July 2012 through June 2018) and the USGS NWQL (analyzed chlorophyll $a$ during June 2017 through September 2019). A total of 16 split-replicate samples were collected at the Wamego and De Soto sites during June 2017 through June 2018 and analyzed by both laboratories. All split-replicate results were considered comparable during the laboratory assessment period (median $\mathrm{RPD}=13.6$ percent; coefficient of determination $\left.\left[R^{2}\right]=0.958\right)$.

Field and equipment blank samples were collected to assess bias caused by sampling procedures and analytical methods (Mueller and others, 2015). A total of 16 field or equipment blank samples were collected at the Wamego and De Soto sites during July 2012 through September 2019. Generally, field and equipment blank sample concentrations were less than or equal to reporting levels for most constituents sampled. Four constituents had detections greater than the laboratory minimum reporting limit (MRL) in blank samples. There were four chloride detections in blank samples; however, all detections were less than the greatest laboratory MRL (0.06 milligram per liter $[\mathrm{mg} / \mathrm{L}]$ ) during the study period. There were two $\mathrm{NO}_{\mathrm{x}}$ detections in blank samples; however, all $\mathrm{NO}_{\mathrm{x}}$ detections were less than the greatest laboratory MRL $(0.04 \mathrm{mg} / \mathrm{L})$ during the study period. There was one total dissolved nitrogen detection in blank samples; however, this detection exceeded the laboratory MRL $(0.05 \mathrm{mg} / \mathrm{L})$ by only $0.01 \mathrm{mg} / \mathrm{L}$. Three total particulate nitrogen detections in blank samples $(0.039,0.055$, and $0.168 \mathrm{mg} / \mathrm{L})$ were greater than the laboratory MRL. The environmental sample concentration associated with the highest blank detection of $0.168 \mathrm{mg} / \mathrm{L}$ was $2.17 \mathrm{mg} / \mathrm{L}$ (percentile rank of 94.1). One other blank sample was collected that coincided with an environmental sample concentration that had a percentile rank greater than 90 . The blank sample concentration associated with this fairly high environmental sample concentration $(2.09 \mathrm{mg} / \mathrm{L}$; percentile rank of 93.6) was less than the laboratory MRL of $0.03 \mathrm{mg} / \mathrm{L}$. Therefore, the environmental sample associated with the blank sample detection of $0.168 \mathrm{mg} / \mathrm{L}$ may be biased high but was likely an isolated occurrence because no other blank sample detections were associated with fairly high environmental sample concentrations (percentile rank greater than 90). Equipment and procedure blank samples were collected for all fecal indicator bacteria samples during July 2012 through September 2019. There were no detections in any fecal indicator bacteria blank samples.

\section{Development and Update of Regression Models}

Linear regression analysis was used to develop models that relate continuous water-quality sensor measurements, streamflow, and seasonal components to discretely sampled water-quality constituent concentrations or densities. Ordinary least squares estimation was used to update or develop models for constituents without censored data (sample results less than the laboratory MRL) in the model calibration dataset. Tobit regression estimation was used to update or develop models for constituents with censored data in the model calibration dataset using the maximum likelihood estimation approach (total suspended solids; $\mathrm{NO}_{\mathrm{x}}$ and E. coli bacteria at the De Soto site; Hald, 1949; Cohen, 1950; Tobin, 1958; Helsel and others, 2020). The regression estimation method and percentages of censored data for each modeled constituent are described in table 1 and appendixes 1-32. Regression models were not updated or developed if more than 50 percent of the data for a discretely sampled constituent were censored as less than the laboratory MRL, as was the case with ammonia at the Wamego and De Soto sites (54-percent censored at each site). High proportions of censored data can result in poor computations of response variable data using linear regression analysis (Helsel, 2012).

Censored data for total nitrogen were handled using an alternative approach. Total nitrogen data were compiled for regression model update by combining total particulate nitrogen and total dissolved nitrogen (Foster and Graham, 2016). There was one instance at both the Wamego and De Soto sites in which a total particulate nitrogen sample result was censored as less than the laboratory MRL, but the associated total dissolved nitrogen result was greater than the laboratory MRL. The associated combined total nitrogen result (total particulate nitrogen plus total dissolved nitrogen) could not be accurately censored as less than a laboratory MRL, which prevented the use of the Tobit regression estimation approach for censored data described previously. Therefore, ordinary least squares estimation was used by arbitrarily substituting one-half of the laboratory MRL for the censored total particulate nitrogen results (one at each site) described previously and then combining the substituted value with the associated total dissolved nitrogen result. This is described in additional detail in appendixes 17-18. This approach can result in poor computations of response variable data using ordinary least squares estimation (Helsel, 2012) but likely had a minor effect on the final selected regression models because of low percentages of data censored as less than the laboratory MRL for total nitrogen at the Wamego and De Soto sites (1.35 and 1.06 percent, respectively). 
Table 1. Linear regression models and summary statistics for computations of continuous water-quality constituent concentrations or densities for the Kansas River at Wamego and Kansas River at De Soto, Kansas, streamgages (U.S. Geological Survey sites 06887500 and 06892350, respectively) using data collected during July 2012 through September 2019.

[Modified from Foster and Graham (2016). R2, coefficient of determination; MSE, mean square error; RMSE, root mean square error; RSE, residual standard error; $M S P E$, model standard percentage error; BCF, bias correction factor; $n$, number of discrete samples used in model development dataset; $\mathrm{mg} / \mathrm{L}$, milligram per liter; $\log$, common logarithm with base $10 ; S C$, continuously measured specific conductance, in microsiemens per centimeter at 25 degrees Celsius; $O L S$, ordinary least squares; App., appendix; --, not applicable; $\mathrm{CaCO}_{3}$, calcium carbonate; fCHL, chlorophyll fluorescence at wavelengths of 650 to 700 nanometers, in relative fluorescence units; sin, sine; $D$, date, in decimal years; $\cos$, cosine; $s N O_{x}$, continuously measured nitrate plus nitrate, in milligrams per liter as nitrogen; $A M L E$, absolute maximum likelihood estimation; <, less than; TBY, turbidity, in formazin nephelometric units; $\mu \mathrm{g} / \mathrm{L}$, microgram per liter; colonies/100 mL, colonies per 100 milliliters $]$

\begin{tabular}{|c|c|c|c|c|c|c|c|c|c|c|c|c|c|c|c|}
\hline \multirow[b]{2}{*}{ Site } & \multirow[b]{2}{*}{ Regression model } & \multirow{2}{*}{$\begin{array}{c}\text { Regression } \\
\text { estimation } \\
\text { method }\end{array}$} & \multirow{2}{*}{$\begin{array}{c}\text { Model } \\
\text { archival } \\
\text { summary }\end{array}$} & \multirow{2}{*}{$\begin{array}{c}\text { Adjusted } \\
R^{2}\end{array}$} & \multirow{2}{*}{$\begin{array}{c}\text { 1Pseudo- } \\
R^{2}\end{array}$} & \multirow[b]{2}{*}{ MSE } & \multirow[b]{2}{*}{ RMSE } & \multirow{2}{*}{$\begin{array}{l}\text { Estimated } \\
\quad R S E \\
\text { (unbiased) }\end{array}$} & \multirow[b]{2}{*}{$\begin{array}{l}\text { Mean } \\
\text { MSPE }\end{array}$} & \multirow{2}{*}{$\begin{array}{c}\text { BCF } \\
\text { (Duan, } \\
\text { 1983) }\end{array}$} & \multicolumn{5}{|c|}{$\begin{array}{l}\text { Discrete data used in } \\
\text { model development dataset }\end{array}$} \\
\hline & & & & & & & & & & & $n$ & $\begin{array}{l}\text { Percent } \\
\text { censored }\end{array}$ & $\begin{array}{c}\text { Range of values } \\
\text { in variable } \\
\text { measurements }\end{array}$ & Mean & Median \\
\hline \multicolumn{16}{|c|}{ Total dissolved solids (TDS), mg/L } \\
\hline Wamego & $\log (T D S)=$ & $O L S$ & App. 1 & 0.970 & -- & 0.000773 & 0.0278 & 0.0278 & 6.40 & 1.00 & 101 & 0 & TDS: $156-810$ & 480 & 474 \\
\hline & $\begin{array}{l}0.940 \log (S C) \\
-0.0278\end{array}$ & & & & & & & & & & & & SC: $262-1,280$ & 762 & 749 \\
\hline De Soto & $\log (T D S)=$ & $O L S$ & App. 2 & 0.966 & -- & 0.000841 & 0.0290 & 0.0290 & 6.69 & 1.00 & 132 & 0 & TDS: $138-876$ & 438 & 443 \\
\hline & $\begin{array}{l}0.962 \log (S C) \\
-0.102\end{array}$ & & & & & & & & & & & & SC: $192-1,350$ & 712 & 714 \\
\hline \multicolumn{16}{|c|}{ Calcium (Ca), dissolved, mg/L } \\
\hline Wamego & $\log (C a)=$ & $O L S$ & App. 3 & 0.876 & -- & 0.00189 & 0.0435 & 0.0435 & 10.0 & 1.00 & 101 & 0 & Ca: $29.6-127$ & 71.4 & 72.1 \\
\hline & $\begin{array}{l}0.690 \log (S C) \\
-0.131\end{array}$ & & & & & & & & & & & & SC: $262-1,280$ & 762 & 749 \\
\hline De Soto & $\log (C a)=$ & $O L S$ & App. 4 & 0.820 & -- & 0.00247 & 0.0497 & 0.0497 & 11.5 & 1.01 & 132 & 0 & Ca: $29.2-113$ & 68.1 & 69.2 \\
\hline & $\begin{array}{l}0.658 \log (S C) \\
-0.0415\end{array}$ & & & & & & & & & & & & SC: $192-1,350$ & 712 & 714 \\
\hline \multicolumn{16}{|c|}{ Magnesium (Mg), dissolved, mg/L } \\
\hline Wamego & $\log (M g)=$ & $O L S$ & App. 5 & 0.889 & -- & 0.00229 & 0.0479 & 0.0479 & 11.1 & 1.01 & 101 & 0 & Mg: 5.90-26.5 & 16.5 & 16.7 \\
\hline & $\begin{array}{l}0.808 \log (S C) \\
-1.11\end{array}$ & & & & & & & & & & & & SC: $262-1,280$ & 762 & 749 \\
\hline De Soto & $\log (M g)=$ & $O L S$ & App. 6 & 0.915 & -- & 0.00179 & 0.0423 & 0.0423 & 9.75 & 1.00 & 132 & 0 & Mg: 5.14-25.0 & 15.7 & 15.6 \\
\hline & $\begin{array}{l}0.861 \log (S C) \\
-1.26\end{array}$ & & & & & & & & & & & & SC: $192-1,350$ & 712 & 714 \\
\hline \multicolumn{16}{|c|}{ Sodium (Na), dissolved, $\mathrm{mg} / \mathrm{L}$} \\
\hline Wamego & $\log (N a)=$ & $O L S$ & App. 7 & 0.950 & -- & 0.00338 & 0.0581 & 0.0581 & 13.4 & 1.01 & 101 & 0 & Na: 9.79-134 & 66.7 & 63.8 \\
\hline & $\begin{array}{l}1.52 \log (S C) \\
-2.57\end{array}$ & & & & & & & & & & & & SC: $262-1,280$ & 762 & 749 \\
\hline De Soto & $\log (N a)=$ & $O L S$ & App. 8 & 0.939 & -- & 0.00489 & 0.0699 & 0.0699 & 16.2 & 1.01 & 132 & 0 & Na: 5.29-149 & 57.8 & 55.7 \\
\hline & $\begin{array}{l}1.70 \log (S C) \\
-3.12\end{array}$ & & & & & & & & & & & & SC: $192-1,350$ & 712 & 714 \\
\hline
\end{tabular}


Table 1. Linear regression models and summary statistics for computations of continuous water-quality constituent concentrations or densities for the Kansas River at Wamego and Kansas River at De Soto, Kansas, streamgages (U.S. Geological Survey sites 06887500 and 06892350, respectively) using data collected during July 2012 through September 2019.-Continued

[Modified from Foster and Graham (2016). $R^{2}$, coefficient of determination; MSE, mean square error; RMSE, root mean square error; RSE, residual standard error; MSPE, model standard percentage error; BCF, bias correction factor; $n$, number of discrete samples used in model development dataset; $\mathrm{mg} / \mathrm{L}$, milligram per liter; $\log$, common logarithm with base $10 ; S C$, continuously measured specific conductance, in microsiemens per centimeter at 25 degrees Celsius; OLS, ordinary least squares; App., appendix; --, not applicable; $\mathrm{CaCO}_{3}$, calcium carbonate; fCHL, chlorophyll fluorescence at wavelengths of 650 to 700 nanometers, in relative fluorescence units; sin, sine; $D$, date, in decimal years; cos, cosine; $S N O_{w}$, continuously measured nitrate plus nitrate, in milligrams per liter as nitrogen; $A M L E$, absolute maximum likelihood estimation; <, less than; TBY, turbidity, in formazin nephelometric units; $\mu \mathrm{g} / \mathrm{L}$, microgram per liter; colonies/100 mL, colonies per $100 \mathrm{milliliters]}$

\begin{tabular}{|c|c|c|c|c|c|c|c|c|c|c|c|c|c|c|c|}
\hline \multirow[b]{2}{*}{ Site } & \multirow[b]{2}{*}{ Regression model } & \multirow{2}{*}{$\begin{array}{l}\text { Regression } \\
\text { estimation } \\
\text { method }\end{array}$} & \multirow{2}{*}{$\begin{array}{c}\text { Model } \\
\text { archival } \\
\text { summary }\end{array}$} & \multirow[b]{2}{*}{$\begin{array}{l}\text { Adjusted } \\
\quad R^{2}\end{array}$} & \multirow{2}{*}{$\begin{array}{l}\text { 1Pseudo- } \\
R^{2}\end{array}$} & \multirow[b]{2}{*}{ MSE } & \multirow[b]{2}{*}{ RMSE } & \multirow{2}{*}{$\begin{array}{c}\text { Estimated } \\
\text { RSE } \\
\text { (unbiased) }\end{array}$} & \multirow[b]{2}{*}{$\begin{array}{l}\text { Mean } \\
\text { MSPE }\end{array}$} & \multirow{2}{*}{$\begin{array}{c}\text { BCF } \\
\text { (Duan, } \\
1983 \text { ) }\end{array}$} & \multicolumn{5}{|c|}{$\begin{array}{l}\text { Discrete data used in } \\
\text { model development dataset }\end{array}$} \\
\hline & & & & & & & & & & & $n$ & $\begin{array}{l}\text { Percent } \\
\text { censored }\end{array}$ & $\begin{array}{c}\text { Range of values } \\
\text { in variable } \\
\text { measurements }\end{array}$ & Mean & Median \\
\hline \multicolumn{16}{|c|}{ Sulfate $\left(\mathrm{SO}_{4}\right)$, dissolved, $\mathrm{mg} / \mathrm{L}$} \\
\hline \multirow[t]{2}{*}{ Wamego } & $\log \left(\mathrm{SO}_{4}\right)=$ & $O L S$ & App. 9 & 0.901 & -- & 0.00377 & 0.0614 & 0.0614 & 14.2 & 1.01 & 101 & 0 & $\mathrm{SO}_{4}: 26.4-243$ & 101 & 98.3 \\
\hline & $\begin{array}{l}1.10 \log (S C) \\
-1.18\end{array}$ & & & & & & & & & & & & SC: $262-1,280$ & 762 & 749 \\
\hline \multirow[t]{2}{*}{ De Soto } & $\log \left(\mathrm{SO}_{4}\right)=$ & $O L S$ & App. 10 & 0.938 & -- & 0.00299 & 0.0547 & 0.0547 & 12.6 & 1.01 & 132 & 0 & $\mathrm{SO}_{4}: 12.7-246$ & 91.8 & 92.5 \\
\hline & $\begin{array}{l}1.32 \log (S C) \\
-1.82\end{array}$ & & & & & & & & & & & & SC: $192-1,350$ & 712 & 714 \\
\hline \multicolumn{16}{|c|}{ Chloride (CI), dissolved, mg/L } \\
\hline \multirow[t]{2}{*}{ Wamego } & $\log (C l)=$ & $O L S$ & App. 11 & 0.939 & -- & 0.00570 & 0.0755 & 0.0755 & 17.5 & 1.01 & 101 & 0 & $\mathrm{Cl}: 10.5-175$ & 82.8 & 80.2 \\
\hline & $\begin{array}{l}1.77 \log (S C) \\
-3.22\end{array}$ & & & & & & & & & & & & SC: $262-1,280$ & 762 & 749 \\
\hline \multirow[t]{2}{*}{ De Soto } & $\log (C l)=$ & $O L S$ & App. 12 & 0.936 & -- & 0.00651 & 0.0807 & 0.0807 & 18.7 & 1.02 & 132 & 0 & Cl: $4.93-200$ & 69.6 & 64.5 \\
\hline & $\begin{array}{l}1.92 \log (S C) \\
-3.67\end{array}$ & & & & & & & & & & & & SC: $192-1,350$ & 712 & 714 \\
\hline \multicolumn{16}{|c|}{ Hardness $\left(\mathrm{CaCO}_{3}\right), \mathrm{mg} / \mathrm{L}$} \\
\hline \multirow[t]{2}{*}{ Wamego } & $\begin{array}{c}\log \left(\mathrm{CaCO}_{3}\right)= \\
0.723 \log (\mathrm{SC})\end{array}$ & $O L S$ & App. 13 & 0.899 & -- & 0.00165 & 0.0406 & 0.0406 & 9.37 & 1.00 & 101 & 0 & $\begin{array}{l}\mathrm{CaCO}_{3}: \\
\quad 98.5-426\end{array}$ & 247 & 249 \\
\hline & +0.314 & & & & & & & & & & & & SC: $262-1,280$ & 762 & 749 \\
\hline \multirow[t]{2}{*}{ De Soto } & $\begin{array}{c}\log \left(\mathrm{CaCO}_{3}\right)= \\
0.712 \log (\mathrm{SC})\end{array}$ & $O L S$ & App. 14 & 0.887 & -- & 0.00167 & 0.0409 & 0.0409 & 9.43 & 1.00 & 132 & 0 & $\begin{array}{l}\mathrm{CaCO}_{3}: \\
\quad 94.5-380\end{array}$ & 235 & 240 \\
\hline & +0.343 & & & & & & & & & & & & SC: $192-1,350$ & 712 & 714 \\
\hline \multicolumn{16}{|c|}{ Nitrate plus nitrite $\left(\mathrm{NO}_{\mathrm{x}}\right)$, dissolved, $\mathrm{mg} / \mathrm{L}$} \\
\hline \multirow[t]{5}{*}{ Wamego } & $N O_{x}=$ & $O L S$ & App. 15 & 0.615 & -- & 0.106 & 0.326 & 0.3330 & 33.0 & -- & 73 & 0 & $\mathrm{NO}_{\mathrm{x}}: 0.030-2.66$ & 0.988 & 0.960 \\
\hline & $-0.00065(S C)$ & & & & & & & & & & & & SC: $277-1,340$ & 737 & 728 \\
\hline & $\begin{array}{l}-0.0995(f C H L) \\
+0.163 \sin (2 \pi D)\end{array}$ & & & & & & & & & & & & fCHL: $0.44-9.80$ & 3.06 & 1.77 \\
\hline & $-0.0823 \cos (2 \pi D)$ & & & & & & & & & & & & & & \\
\hline & +1.77 & & & & & & & & & & & & & & \\
\hline
\end{tabular}


Table 1. Linear regression models and summary statistics for computations of continuous water-quality constituent concentrations or densities for the Kansas River at Wamego and Kansas River at De Soto, Kansas, streamgages (U.S. Geological Survey sites 06887500 and 06892350 , respectively) using data collected during July 2012 through September 2019.-Continued

[Modified from Foster and Graham (2016). $R^{2}$, coefficient of determination; MSE, mean square error; RMSE, root mean square error; RSE, residual standard error; $M S P E$, model standard percentage error; BCF, bias correction factor; $n$, number of discrete samples used in model development dataset; $\mathrm{mg} / \mathrm{L}$, milligram per liter; log, common logarithm with base $10 ; S C$, continuously measured specific conductance, in microsiemens per centimeter at 25 degrees Celsius; OLS, ordinary least squares; App., appendix; --, not applicable; $\mathrm{CaCO}_{3}$, calcium carbonate; fCHL, chlorophyll fluorescence at wavelengths of 650 to 700 nanometers, in relative fluorescence units; sin, sine; $D$, date, in decimal years; cos, cosine; $s N O_{x}$, continuously measured nitrate plus nitrate, in milligrams per liter as nitrogen; $A M L E$, absolute maximum likelihood estimation; <, less than; TBY, turbidity, in formazin nephelometric units; $\mu \mathrm{g} / \mathrm{L}$, microgram per liter; colonies/100 mL, colonies per 100 milliliters]

\begin{tabular}{|c|c|c|c|c|c|c|c|c|c|c|c|c|c|c|c|}
\hline \multirow[b]{2}{*}{ Site } & \multirow[b]{2}{*}{ Regression model } & \multirow{2}{*}{$\begin{array}{c}\text { Regression } \\
\text { estimation } \\
\text { method }\end{array}$} & \multirow{2}{*}{$\begin{array}{c}\text { Model } \\
\text { archival } \\
\text { summary }\end{array}$} & \multirow{2}{*}{$\begin{array}{l}\text { Adjusted } \\
\quad R^{2}\end{array}$} & \multirow{2}{*}{$\begin{array}{l}\text { 1Pseudo- } \\
\qquad R^{2}\end{array}$} & \multirow[b]{2}{*}{ MSE } & \multirow[b]{2}{*}{ RMSE } & \multirow{2}{*}{$\begin{array}{l}\text { Estimated } \\
\quad R S E \\
\text { (unbiased) }\end{array}$} & \multirow{2}{*}{$\begin{array}{l}\text { Mean } \\
\text { MSPE }\end{array}$} & \multirow{2}{*}{$\begin{array}{l}\text { BCF } \\
\text { (Duan, } \\
1983 \text { ) }\end{array}$} & \multicolumn{5}{|c|}{$\begin{array}{l}\text { Discrete data used in } \\
\text { model development dataset }\end{array}$} \\
\hline & & & & & & & & & & & $n$ & $\begin{array}{l}\text { Percent } \\
\text { censored }\end{array}$ & $\begin{array}{l}\text { Range of values } \\
\text { in variable } \\
\text { measurements }\end{array}$ & Mean & Median \\
\hline \multicolumn{16}{|c|}{ Nitrate plus nitrite $\left(\mathrm{NO}_{\mathrm{x}}\right)$, dissolved, $\mathrm{mg} / \mathrm{L}-$ Continued } \\
\hline De Soto & $\begin{array}{l}N O_{x}= \\
\quad 1.02\left(s N O_{x}\right) \\
\quad-0.325\end{array}$ & $A M L E$ & App. 16 & -- & 0.898 & -- & -- & 0.221 & -- & -- & 84 & 23.8 & $\begin{array}{l}\mathrm{NO}_{\mathrm{x}}:<0.01-2.20 \\
\mathrm{sNO}_{\mathrm{x}}: \\
\quad 0.0678-2.26\end{array}$ & $\begin{array}{l}0.667 \\
1.02\end{array}$ & $\begin{array}{l}0.776 \\
1.13\end{array}$ \\
\hline \multicolumn{16}{|c|}{ Nitrogen, total (TN), mg/L; total particulate nitrogen plus dissolved nitrogen } \\
\hline Wamego & $\begin{array}{l}\log (T N)= \\
\quad 0.281 \log (T B Y) \\
\quad-0.184 \log (f C H L) \\
\quad+0.0716 \sin (2 \pi D) \\
\quad+0.00669 \cos (2 \pi D) \\
\quad-0.154\end{array}$ & $O L S$ & App. 17 & 0.814 & -- & 0.00704 & 0.0839 & 0.0857 & 19.4 & 1.02 & 74 & 1.35 & $\begin{array}{l}\text { TN: } 0.735-4.35 \\
\text { TBY: } 7.42-557 \\
\text { fCHL: } 0.44-9.80\end{array}$ & $\begin{array}{c}2.11 \\
116 \\
3.09\end{array}$ & $\begin{array}{c}1.90 \\
58.8 \\
1.77\end{array}$ \\
\hline De Soto & $\begin{array}{l}\log (T N)= \\
\quad 0.327 \log (T B Y) \\
\quad-0.0994 \log (f C H L) \\
\quad+0.0758 \sin (2 \pi D) \\
\quad+0.0306 \cos (2 \pi D) \\
\quad-0.275\end{array}$ & $O L S$ & App. 18 & 0.845 & -- & 0.00740 & 0.086 & 0.0874 & 19.9 & 1.02 & 94 & 1.06 & $\begin{array}{l}\text { TN: } 0.763-8.94 \\
\text { TBY: } 6.06-1,110 \\
\text { fCHL: } 0.30-36.9\end{array}$ & $\begin{array}{c}2.12 \\
147 \\
6.32\end{array}$ & $\begin{array}{c}1.83 \\
59.0 \\
2.76\end{array}$ \\
\hline \multicolumn{16}{|c|}{ Phosphorus, total (TP), mg/L } \\
\hline Wamego & $\begin{array}{l}\log (T P)= \\
0.329 \log (T B Y) \\
-0.909\end{array}$ & $O L S$ & App. 19 & 0.788 & -- & 0.00697 & 0.0835 & 0.0835 & 19.3 & 1.02 & 85 & 0 & $\begin{array}{l}\text { TP: } 0.210-1.38 \\
\text { TBY: } 7.42-557\end{array}$ & $\begin{array}{l}0.508 \\
105\end{array}$ & $\begin{array}{l}0.440 \\
50.2\end{array}$ \\
\hline De Soto & $\begin{array}{l}\log (T P)= \\
\quad 0.390 \log (T B Y) \\
-1.05\end{array}$ & $O L S$ & App. 20 & 0.793 & -- & 0.0119 & 0.109 & 0.109 & 25.4 & 1.03 & 109 & 0 & $\begin{array}{l}\text { TP: } 0.200-2.85 \\
\text { TBY: } \\
\quad 6.06-1,530\end{array}$ & $\begin{array}{l}0.537 \\
149\end{array}$ & $\begin{array}{l}0.39 \\
52.0\end{array}$ \\
\hline
\end{tabular}


Table 1. Linear regression models and summary statistics for computations of continuous water-quality constituent concentrations or densities for the Kansas River at

Wamego and Kansas River at De Soto, Kansas, streamgages (U.S. Geological Survey sites 06887500 and 06892350, respectively) using data collected during July 2012 through September 2019.-Continued

[Modified from Foster and Graham (2016). $R^{2}$, coefficient of determination; MSE, mean square error; RMSE, root mean square error; RSE, residual standard error; MSPE, model standard percentage error; BCF, bias correction factor; $n$, number of discrete samples used in model development dataset; $\mathrm{mg} / \mathrm{L}$, milligram per liter; log, common logarithm with base $10 ; S C$, continuously measured specific conductance, in microsiemens per centimeter at 25 degrees Celsius; $O L S$, ordinary least squares; App., appendix; --, not applicable; $\mathrm{CaCO}_{3}$, calcium carbonate; fCHL, chlorophyll fluorescence at wavelengths of 650 to 700 nanometers, in relative fluorescence units; sin, sine; $D$, date, in decimal years; $\cos$, cosine; $s N O_{x}$, continuously measured nitrate plus nitrate, in milligrams per liter as nitrogen; $A M L E$, absolute maximum likelihood estimation; <, less than; TBY, turbidity, in formazin nephelometric units; $\mu \mathrm{g} / \mathrm{L}$, microgram per liter; colonies/100 mL, colonies per 100 milliliters]

\begin{tabular}{|c|c|c|c|c|c|c|c|c|c|c|c|c|c|c|c|}
\hline \multirow[b]{2}{*}{ Site } & \multirow[b]{2}{*}{ Regression model } & \multirow{2}{*}{$\begin{array}{c}\text { Regression } \\
\text { estimation } \\
\text { method }\end{array}$} & \multirow{2}{*}{$\begin{array}{l}\text { Model } \\
\text { archival } \\
\text { summary }\end{array}$} & \multirow{3}{*}{$\begin{array}{c}\text { Adjusted } \\
R^{2}\end{array}$} & \multirow{3}{*}{$\begin{array}{c}\text { 1Pseudo- } \\
R^{2}\end{array}$} & \multirow[b]{2}{*}{ MSE } & \multirow[b]{2}{*}{ RMSE } & \multirow{2}{*}{$\begin{array}{c}\text { Estimated } \\
\quad R S E \\
\text { (unbiased) }\end{array}$} & \multirow{2}{*}{$\begin{array}{l}\text { Mean } \\
\text { MSPE }\end{array}$} & \multirow{2}{*}{$\begin{array}{c}\text { BCF } \\
\text { (Duan, } \\
1983 \text { ) }\end{array}$} & \multicolumn{5}{|c|}{$\begin{array}{l}\text { Discrete data used in } \\
\text { model development dataset }\end{array}$} \\
\hline & & & & & & & & & & & $n$ & $\begin{array}{l}\text { Percent } \\
\text { censored }\end{array}$ & $\begin{array}{c}\text { Range of values } \\
\text { in variable } \\
\text { measurements }\end{array}$ & Mean & Median \\
\hline \multicolumn{14}{|c|}{ Chlorophyll $a_{1}$ (Chla), $\mu \mathrm{g} / \mathrm{L}$} & & \\
\hline \multirow{2}{*}{ Wamego } & $\log (C h l a)=$ & $O L S$ & App. 21 & 0.852 & -- & 0.0357 & 0.189 & 0.189 & 44.9 & 1.09 & 74 & 0 & Chla: $1.20-88.3$ & 24.2 & 14.3 \\
\hline & $\begin{array}{l}1.28 \log (f C H L) \\
+0.699\end{array}$ & & & & & & & & & & & & fCHL: $0.44-9.80$ & 3.09 & 1.77 \\
\hline \multirow[t]{2}{*}{ De Soto } & $\log ($ Chla $)=$ & $O L S$ & App. 22 & 0.902 & -- & 0.0292 & 0.171 & 0.171 & 40.4 & 1.08 & 78 & 0 & Chla: $1.42-187$ & 40.9 & 24.3 \\
\hline & $\begin{array}{l}1.08 \log (f C H L) \\
+0.751\end{array}$ & & & & & & & & & & & & fCHL: $0.30-36.9$ & 6.21 & 2.76 \\
\hline \multicolumn{16}{|c|}{ Total suspended solids, (TSS), mg/L } \\
\hline \multirow[t]{2}{*}{ Wamego } & $\begin{array}{l}\log (T S S)= \\
\quad 1.05 \log (T B Y)\end{array}$ & $A M L E$ & App. 23 & -- & 0.893 & -- & -- & 0.178 & -- & 1.08 & 78 & 6.41 & $\begin{array}{l}\text { TSS: } \\
\quad<15.0-1,830\end{array}$ & 200 & 84.0 \\
\hline & +0.167 & & & & & & & & & & & & TBY: 7.42-557 & 101 & 50.2 \\
\hline \multirow[t]{2}{*}{ De Soto } & $\begin{array}{l}\log (T S S)= \\
\quad 1.03 \log (T B Y)\end{array}$ & $A M L E$ & App. 24 & -- & 0.966 & -- & -- & 0.110 & -- & 1.03 & 79 & 5.06 & $\begin{array}{l}\text { TSS: } \\
\quad<15.0-2,920\end{array}$ & 340 & 96.0 \\
\hline & +0.226 & & & & & & & & & & & & TBY: $6.1-1,530$ & 166 & 58.0 \\
\hline \multicolumn{16}{|c|}{ Suspended-sediment concentration (SSC), mg/L } \\
\hline \multirow[t]{2}{*}{ Wamego } & $\log (\mathrm{SSC})=$ & $O L S$ & App. 25 & 0.876 & -- & 0.0357 & 0.189 & 0.189 & 45.0 & 1.12 & 84 & 0 & SSC: $16-2,990$ & 323 & 162 \\
\hline & $\begin{array}{l}0.998 \log (T B Y) \\
+0.425\end{array}$ & & & & & & & & & & & & TBY: 7.42-907 & 116 & 51.9 \\
\hline \multirow[t]{2}{*}{ De Soto } & $\log (\mathrm{SSC})=$ & $O L S$ & App. 26 & 0.933 & -- & 0.0243 & 0.156 & 0.156 & 36.6 & 1.07 & 105 & 0 & SSC: $8-3,730$ & 437 & 131 \\
\hline & $\begin{array}{l}1.05 \log (T B Y) \\
+0.275\end{array}$ & & & & & & & & & & & & $\begin{array}{l}\text { TBY: } \\
\quad 6.06-1,530\end{array}$ & 165 & 58.1 \\
\hline \multicolumn{16}{|c|}{ Escherichia coli bacteria (ECB), colonies/100 mL } \\
\hline \multirow[t]{2}{*}{ Wamego } & $\begin{array}{l}\log (E C B)= \\
\quad 1.27 \log (T B Y)\end{array}$ & $O L S$ & App. 27 & 0.598 & -- & 0.263 & 0.513 & 0.513 & 148 & 1.90 & 78 & 0 & $\begin{array}{l}\text { ECB: } \\
\quad 3.00-18,000\end{array}$ & 734 & 58.0 \\
\hline & -0.304 & & & & & & & & & & & & TBY: $7.42-557$ & 107 & 51.1 \\
\hline
\end{tabular}


Table 1. Linear regression models and summary statistics for computations of continuous water-quality constituent concentrations or densities for the Kansas River at Wamego and Kansas River at De Soto, Kansas, streamgages (U.S. Geological Survey sites 06887500 and 06892350, respectively) using data collected during July 2012 through September 2019.-Continued

[Modified from Foster and Graham (2016). R2, coefficient of determination; $M S E$, mean square error; RMSE, root mean square error; RSE, residual standard error; $M S P E$, model standard percentage error; BCF, bias correction factor; $n$, number of discrete samples used in model development dataset; $\mathrm{mg} / \mathrm{L}$, milligram per liter; log, common logarithm with base $10 ; S C$, continuously measured specific conductance, in microsiemens per centimeter at 25 degrees Celsius; OLS, ordinary least squares; App., appendix; --, not applicable; $\mathrm{CaCO}_{3}$, calcium carbonate; fCHL, chlorophyll fluorescence at wavelengths of 650 to 700 nanometers, in relative fluorescence units; sin, sine; $D$, date, in decimal years; cos, cosine; $s N O_{x}$, continuously measured nitrate plus nitrate, in milligrams per liter as nitrogen; $A M L E$, absolute maximum likelihood estimation; <, less than; $T B Y$, turbidity, in formazin nephelometric units; $\mu \mathrm{g} / \mathrm{L}$, microgram per liter; colonies/100 mL, colonies per $100 \mathrm{milliliters]}$

\begin{tabular}{|c|c|c|c|c|c|c|c|c|c|c|c|c|c|c|c|}
\hline \multirow[b]{2}{*}{ Site } & \multirow[b]{2}{*}{ Regression model } & \multirow{2}{*}{$\begin{array}{c}\text { Regression } \\
\text { estimation } \\
\text { method }\end{array}$} & \multirow{2}{*}{$\begin{array}{c}\text { Model } \\
\text { archival } \\
\text { summary }\end{array}$} & \multirow{2}{*}{$\begin{array}{c}\text { Adjusted } \\
R^{2}\end{array}$} & \multirow{2}{*}{$\begin{array}{c}\text { 1Pseudo- } \\
R^{2}\end{array}$} & \multirow[b]{2}{*}{ MSE } & \multirow[b]{2}{*}{ RMSE } & \multirow{2}{*}{$\begin{array}{c}\text { Estimated } \\
\text { RSE } \\
\text { (unbiased) }\end{array}$} & \multirow[b]{2}{*}{$\begin{array}{l}\text { Mean } \\
\text { MSPE }\end{array}$} & \multirow{2}{*}{$\begin{array}{c}\text { BCF } \\
\text { (Duan, } \\
\text { 1983) }\end{array}$} & \multicolumn{5}{|c|}{$\begin{array}{l}\text { Discrete data used in } \\
\text { model development dataset }\end{array}$} \\
\hline & & & & & & & & & & & $n$ & $\begin{array}{l}\text { Percent } \\
\text { censored }\end{array}$ & $\begin{array}{c}\text { Range of values } \\
\text { in variable } \\
\text { measurements }\end{array}$ & Mean & Median \\
\hline \multicolumn{16}{|c|}{ Escherichia colibacteria (ECB), colonies $/ 100 \mathrm{~mL}$-Continued } \\
\hline \multirow[t]{2}{*}{ De Soto } & $\begin{array}{l}\log (E C B)= \\
1.68 \log (T B Y)\end{array}$ & $A M L E$ & App. 28 & -- & 0.822 & -- & -- & 0.439 & -- & 1.60 & 77 & 1.30 & $\begin{array}{l}\text { ECB: } \\
\quad<1.0-22,000\end{array}$ & 1,590 & 77.0 \\
\hline & -1.02 & & & & & & & & & & & & TBY: $6.1-1,530$ & 162 & 58.0 \\
\hline \multicolumn{16}{|c|}{ Fecal coliform bacteria (FCB), colonies $/ 100 \mathrm{~mL}$} \\
\hline \multirow[t]{2}{*}{ Wamego } & $\begin{array}{l}\log (F C B)= \\
\quad 0.968 \log (T B Y)\end{array}$ & $O L S$ & App. 29 & 0.658 & -- & 0.227 & 0.476 & 0.482 & 133 & 1.78 & 77 & 0 & $\begin{array}{l}\text { FCB: } \\
\quad 7.00-14,000\end{array}$ & 921 & 140 \\
\hline & $\begin{array}{l}-0.286 \times \sin (2 \pi D) \\
-0.339 \cos (2 \pi D) \\
+0.442\end{array}$ & & & & & & & & & & & & TBY: $7.42-557$ & 108 & 52.0 \\
\hline \multirow[t]{2}{*}{ De Soto } & $\begin{array}{l}\log (F C B)= \\
1.28 \log (T B Y)\end{array}$ & $O L S$ & App. 30 & 0.806 & -- & 0.188 & 0.434 & 0.440 & 117 & 1.60 & 75 & 0 & $\begin{array}{l}\text { FCB: } \\
1.00-19,000\end{array}$ & 1,640 & 220 \\
\hline & $\begin{array}{l}-0.438 \times \sin (2 \pi D) \\
-0.296 \cos (2 \pi D) \\
-0.0872\end{array}$ & & & & & & & & & & & & TBY: $6.1-1,530$ & 158 & 59.0 \\
\hline \multicolumn{16}{|c|}{ Enterococci bacteria (ENT), colonies/100 mL } \\
\hline \multirow[t]{2}{*}{ Wamego } & $\begin{array}{l}\log (E N T)= \\
\quad 1.03 \log (T B Y)\end{array}$ & $O L S$ & App. 31 & 0.530 & -- & 0.218 & 0.467 & 0.467 & 129 & 1.73 & 77 & 0 & $\begin{array}{l}\text { ENT: } \\
\quad 15.0-17,000\end{array}$ & 1,030 & 190 \\
\hline & +0.578 & & & & & & & & & & & & TBY: $7.42-557$ & 101 & 50.2 \\
\hline \multirow[t]{2}{*}{ De Soto } & $\begin{array}{l}\log (E N T)= \\
\quad 1.38 \log (T B Y)\end{array}$ & $O L S$ & App. 32 & 0.754 & -- & 0.187 & 0.433 & 0.433 & 117 & 1.62 & 76 & 0 & $\begin{array}{l}\text { ENT: } \\
\quad 4.00-18,000\end{array}$ & 1,350 & 158 \\
\hline & -0.295 & & & & & & & & & & & & TBY: $6.1-1,530$ & 153 & 56.2 \\
\hline
\end{tabular}

${ }^{1}$ Pseudo- $R^{2}$ is computed using the McKelvey and Zavoina (1975) method. For uncensored data, it is equal to the $R^{2}$ for ordinary least squares. 
Occasionally, discrete water-quality sample results were qualified as "estimated" for analytical purposes. Results were qualified as "estimated" for chlorophyll $a$ and E. coli, fecal coliform, and enterococci bacteria at the Wamego and De Soto sites. Estimated results were included in the model calibration dataset and then investigated as potential outliers. There was no evidence to remove any results qualified as "estimated" based on outlier identification methods described by Rasmussen and others (2009). The number of estimated results included in each model calibration dataset is provided in appendixes 21-22 and 27-32.

Several regression models were updated from previously published versions documented in Foster and Graham (2016), including models computing concentrations of total dissolved solids, calcium, magnesium, sodium, sulfate, chloride, $\mathrm{NO}_{\mathrm{x}}$ (Wamego site only), total nitrogen (total particulate nitrogen plus total dissolved nitrogen; Foster and Graham, 2016), total phosphorus (Wamego site only), suspended sediment, and E. coli, fecal coliform, and enterococci bacteria (De Soto site only). Additional water-quality data collected during the current study period were used to develop new models that compute concentrations or densities of hardness as calcium carbonate, chlorophyll $a$, and total suspended solids; $\mathrm{NO}_{\mathrm{x}}$ and total phosphorus at the De Soto site; and E. coli, fecal coliform, and enterococci bacteria at the Wamego site. All linear regression models were developed using $\mathrm{R}$ programming language (R Core Team, 2020).

Potential explanatory variables were evaluated individually and in combination including continuous streamflow, water temperature, specific conductance, dissolved oxygen, $\mathrm{pH}$, turbidity, chlorophyll and phycocyanin fluorescence, and optical $\mathrm{NO}_{\mathrm{x}}$ (at the De Soto site only) data. These potential explanatory variables were interpolated within the 15-minute continuous record based on discrete sample time. The maximum time span between two continuous data points used for interpolation was 2 hours. Occasionally, there were gaps in the continuous record that exceeded 2 hours because of excessive fouling, equipment malfunction, or temporary removal. In these cases, cross-sectional means collected from field waterquality monitors during each discrete water-quality sample were used. Seasonal components (sine and cosine variables) also were evaluated as potential explanatory variables (if the sine or cosine variable was an explanatory variable, both variables were included, regardless of statistical significance).

Potential linear regression models were evaluated based on patterns in residual plots, range and distribution of continuous and discrete data, and the following diagnostic statistics: adjusted $R^{2}$, pseudo- $R^{2}$ (computed for Tobit regression models; McKelvey and Zavoina, 1975), Mallows' $C_{p}$, root mean square error (RMSE), and prediction error sum of squares (PRESS; Rasmussen and others, 2009; Helsel and others, 2020). Linear regression models were selected when variance in the response variable(s) explained by the model was maximized (as indicated by adjusted $R^{2}$ or pseudo- $R^{2}$ ), model precision was high with low bias (as indicated by Mallows' $C_{p}$ ), uncertainty associated with computed values was minimized (as indicated by RMSE and PRESS), and heteroscedasticity (irregular scatter) was minimized (as observed in residual plots; Rasmussen and others, 2009; Helsel and others, 2020). Potential explanatory variables were only considered if they had a probability ( $p$-value) less than 0.05. Potential outliers were identified using methods described in Rasmussen and others (2009). Additionally, computations of studentized residuals, leverage, and Cook's distance were used to estimate potential outlier effect on the final selected regression model (Cook, 1977; Helsel and others, 2020). All outliers removed from linear regression analyses are identified, and justification for removal is included, in appendixes 1-32.

In addition to model selection criteria, model simplicity and previously published explanatory variables (Rasmussen and others, 2005; Foster and Graham, 2016) were considered during the selection process. Additional explanatory variables were considered for linear regression models if they increased the variance explained by the model by 5 percent or more, had a $p$-value less than 0.05 , decreased Mallows' $C_{p}$, minimized $R M S E$ and PRESS, and minimized heteroscedasticity in residual plots. Multiple explanatory variables were only selected if the associated variance inflation factor (VIF; Marquardt, 1970) for each explanatory variable was less than 4 , indicating minimal multicollinearity (O'brien, 2007; Vatcheva and others, 2016; Helsel and others, 2020). Models were considered suitable to continuously compute water-quality constituent concentrations or densities only if the variance explained by the model (as indicated by adjusted $R^{2}$ or pseudo- $R^{2}$ ) was greater than or equal to 0.50 .

Common logarithmic transformations (logarithm with base 10; log transformations) of the response and explanatory variables were considered when heteroscedasticity was present in plots of residuals compared to computed values (included in appendixes 1-32). If the final selected linear regression model contained log transformations, a bias correction factor was computed for the retransformation of computed results back into their original units (Duan, 1983). This reduced the inherent negative bias caused by log transformations (Helsel and others, 2020). Methods used for model development are described in more detail in Foster and Graham (2016) and Rasmussen and others (2009) and appendixes 1-32.

\section{Developed and Updated Regression Models}

Linear regression models that continuously compute water-quality constituent concentrations or densities were updated or developed for 16 water-quality constituents at the Wamego and De Soto sites. Constituents that were modeled were total dissolved solids and major ions (calcium, magnesium, sodium, sulfate, and chloride), hardness as calcium carbonate, nutrients $\left(\mathrm{NO}_{\mathrm{x}}\right.$, total nitrogen, and total phosphorus), chlorophyll $a$, total suspended solids, suspended sediment, and fecal indicator bacteria (E. coli, fecal coliform, and 
enterococci). A single model was selected for each constituent at the Wamego and De Soto sites. Models, model selection criteria results, and summary statistics are provided in table 1. Model archive summaries containing model development information, statistical model output (R Core Team, 2020), and model datasets for each model are provided in appendixes $1-32$.

\section{Total Dissolved Solids, Major Ions, and Hardness}

The singular explanatory variable for total dissolved solids, major ions, and hardness (as calcium carbonate) models was specific conductance at the Wamego and De Soto sites (table 1; appendixes 1-14) because of its positive correlation with total dissolved solids and other charged ionic species (Hem, 1992). Specific conductance explained about 82-97 percent of the variance (as indicated by adjusted $R^{2}$ ) in total dissolved solids, major ions, and hardness concentrations (table 1; appendixes 1-14). Specific conductance also was used as the singular explanatory variable for total dissolved solids and major ions models previously published by Foster and Graham (2016). There were no previously published hardness models at these sites.

\section{Nitrate Plus Nitrite, Total Nitrogen, Total Phosphorus, and Chlorophyll a}

Explanatory variables for $\mathrm{NO}_{\mathrm{x}}$ varied by site. At the Wamego site, explanatory variables were specific conductance, chlorophyll fluorescence, and seasonal components (sine and cosine variables), which explained about 62 percent of the variance in $\mathrm{NO}_{\mathrm{x}}$ concentration (table 1; appendix 15). The addition of chlorophyll fluorescence as an explanatory variable increased the amount of variance explained by the Wamego $\mathrm{NO}_{\mathrm{x}}$ model by about 14 percent, compared to using only specific conductance as an explanatory variable. Further, the addition of seasonal components as explanatory variables increased the amount of variance explained by the model by 5 percent, compared to using only specific conductance and chlorophyll fluorescence as explanatory variables. The VIFs for specific conductance, chlorophyll fluorescence, and seasonal components were less than 2 at the Wamego site, indicating minimal multicollinearity. Specific conductance and chlorophyll fluorescence also were used as explanatory variables in the Wamego model previously published by Foster and Graham (2016). Seasonality is likely related to $\mathrm{NO}_{\mathrm{x}}$ because increases have historically been associated with seasonal precipitation runoff events in the Kansas River (Rasmussen and others, 2005; Graham and others, 2018). At the De Soto site, the single explanatory variable for $\mathrm{NO}_{\mathrm{x}}$ was an optical $\mathrm{NO}_{\mathrm{x}}$ sensor (deployed at the De Soto site only), which explained about 90 percent of the variance in $\mathrm{NO}_{\mathrm{x}}$ concentration (as indicated by pseudo- $R^{2}$; table 1 ; appendix 16 ).
There was not a previously published $\mathrm{NO}_{\mathrm{x}}$ model at the De Soto site (Foster and Graham, 2016). The difference in explanatory variables for $\mathrm{NO}_{\mathrm{x}}$ models at each site was mainly due to the additional continuous monitoring equipment (optical $\mathrm{NO}_{\mathrm{x}}$ sensor) available at the De Soto site.

Explanatory variables for total nitrogen (total particulate nitrogen plus total dissolved nitrogen) models were turbidity, chlorophyll fluorescence, and seasonal components, which explained about 81 and 85 percent of the variance in total nitrogen concentration at the Wamego and De Soto sites, respectively (table 1; appendixes 17-18). The addition of chlorophyll fluorescence as an explanatory variable increased the amount of variance explained by the total nitrogen models by about 15 and 13 percent at the Wamego and De Soto sites, respectively, compared to using turbidity as a single explanatory variable. Further, the addition of seasonal components as explanatory variables increased the amount of variance explained by the total nitrogen models by about 6 percent at the Wamego and De Soto sites compared to using only turbidity and chlorophyll fluorescence as explanatory variables. The VIFs for turbidity, chlorophyll fluorescence, and seasonal components were less than 2 at both sites, indicating minimal multicollinearity. Turbidity and seasonal components are likely related to total nitrogen concentration because increases in total nitrogen can be associated with seasonal runoff events that increase turbidity. The optical $\mathrm{NO}_{\mathrm{x}}$ sensor (deployed at the De Soto site only) was not selected as an explanatory variable for total nitrogen at the De Soto site because particulate nitrogen represented 50 percent or more of total nitrogen in about 40 percent of the samples collected during the study. Additionally, use of the optical $\mathrm{NO}_{\mathrm{x}}$ sensor as an explanatory variable for total nitrogen at the De Soto site truncated the model calibration dataset from 94 to 66 observations. Total nitrogen models previously published by Foster and Graham (2016) used turbidity, chlorophyll fluorescence, and water temperature as explanatory variables.

The singular explanatory variable for total phosphorus models was turbidity, which explained about 79 percent of variance in total phosphorus concentration at both study sites, respectively (table 1; appendixes 19-20). Phosphorus can physically bind to suspended sediment, which makes turbidity a logical explanatory variable for total phosphorus concentrations. In addition to turbidity, the Wamego total phosphorus model previously published by Foster and Graham (2016) used seasonality as an explanatory variable. Foster and Graham (2016) did not publish a total phosphorus model for the De Soto site.

The singular explanatory variable for chlorophyll $a$ was chlorophyll fluorescence, which explained about 85 and 90 percent of variance in chlorophyll $a$ concentration at the Wamego and De Soto sites, respectively (table 1; appendixes 21-22). Chlorophyll $a$ pigments fluoresce when irradiated by certain wavelengths of light, which makes chlorophyll fluorescence an appropriate explanatory variable for chlorophyll $a$ concentration. There were no previously published chlorophyll $a$ models at these sites (Foster and Graham, 2016). 


\section{Total Suspended Solids and Suspended Sediment}

The singular explanatory variable for the total suspended solids and suspended-sediment models was turbidity, which explained about 89 and 97 percent of the variance in total suspended solids concentration, and about 88 and 93 percent of the variance in suspended-sediment concentration, at the Wamego and De Soto sites, respectively (table 1; appendixes 23-26). Turbidity is positively related to suspended material and is a logical explanatory variable for total suspended solids and suspended-sediment concentration. Foster and Graham (2016) did not publish total suspended solids models at either site. Suspended-sediment concentration models previously published by Foster and Graham (2016) also used turbidity as the single explanatory variable.

\section{Fecal Indicator Bacteria}

The singular explanatory variable for $E$. coli and enterococci bacteria was turbidity, which explained about 60 and 82 percent of the variance in E. coli bacteria density and about 53 and 75 percent of the variance in enterococci bacteria density at the Wamego and De Soto sites, respectively (table 1; appendixes $27-28$ and 31-32). Turbidity and seasonal components were selected as explanatory variables for fecal coliform bacteria, which explained about 66 and 81 percent of the variance in fecal coliform bacteria at the Wamego and De Soto sites, respectively (table 1; appendixes 29-30). The addition of seasonal components as explanatory variables increased the amount of variance explained by the fecal coliform models by about 11 and 12 percent at the Wamego and De Soto sites, respectively, compared to using turbidity as a single explanatory variable. The VIFs for turbidity and seasonal components were less than 2 at both sites, indicating minimal multicollinearity. Fecal indicator bacteria can physically bind to suspended sediment, which makes turbidity a logical explanatory variable for E. coli, fecal coliform, and enterococci bacteria. Increases in turbidity during seasonal precipitation runoff events also makes seasonality a logical explanatory variable for fecal coliform bacteria.

\section{Summary}

The Kansas River supplies drinking water to about 800,000 people in northeastern Kansas. Water-treatment facilities that use the Kansas River as a source use various chemical and physical processes to remove contaminants before distribution. An advanced notification system of changing water-quality conditions near water-supply intakes provides water-treatment facilities the ability to proactively treat their water supply. The U.S. Geological Survey (USGS), in cooperation with the Kansas Water Office (funded in part through the Kansas Water Plan), the Kansas Department of Health and Environment, The Nature Conservancy, the City of Lawrence, the City of Manhattan, the City of Olathe, the City of Topeka, and Johnson County WaterOne, collected water-quality data at the Kansas River at Wamego (USGS site 06887500; hereafter referred to as the "Wamego site") and De Soto (USGS site 06892350; hereafter referred to as the "De Soto site") monitoring sites to update previously published regression models relating continuous water-quality sensor measurements, streamflow, and seasonal components to discretely sampled water-quality constituent concentrations or densities. These regression models continuously compute water-quality constituent concentrations or densities that are not easily measured in near-real time.

Continuous and discrete water-quality monitoring data collected during July 2012 through September 2019 were used to update previously published regression models at the Wamego and De Soto sites with the primary intent to provide advanced notification of changing water-quality conditions for constituents of interest in the Kansas River. This report updates regression models for total dissolved solids and major ions, nutrients (nitrogen and phosphorus species), suspended sediment, and fecal indicator bacteria at the Wamego and De Soto sites. Additional samples collected during July 2012 through September 2019 were used to develop new linear regression models, including hardness as calcium carbonate, chlorophyll $a$, and total suspended solids; nitrate plus nitrite and total phosphorus at the De Soto site; and Escherichia coli, fecal coliform, and enterococci bacteria at the Wamego site. This report documents regression model updates and development. Continuous and discrete water-quality monitoring data used in regression model updates and development are available in appendixes 1-32 and from the USGS National Water Information System database. Real-time computations of water-quality constituent concentrations or densities using the models documented in this report are available at the USGS National Real-Time Water Quality website (https://nrtwq.usgs.gov). The water-quality information in this report can be used by water-treatment facilities to aid in treatment decisions. Additionally, the regression-computed concentrations from the models documented in this report are useful for comparison to Federal and State water-quality criteria, for computation of loads and yields to evaluate constituent transport through the drainage basin, and for characterization of changes in water-quality conditions in the Kansas River through time.

\section{References Cited}

Arar, E.J., and Collins, G.B., 1997, Method 445.0-In vitro determination of chlorophyll $a$ and pheophytin $a$ in marine and freshwater algae by fluorescence (rev. 1.2): U.S. Environmental Protection Agency, Office of Research and Development, $22 \mathrm{p}$. 
Bennett, T.J., Graham, J.L., Foster, G.M., Stone, M.L., Juracek, K.E., Rasmussen, T.J., and Putnam, J.E., 2014, U.S. Geological Survey quality-assurance plan for continuous water-quality monitoring in Kansas, 2014: U.S. Geological Survey Open-File Report 2014-1151, 34 p. plus appendixes, accessed July 2020 at https://doi.org/ 10.3133/ofr20141151.

Cohen, A.C., Jr., 1950, Estimating the mean and variance of normal populations from singly truncated and doubly truncated samples: Annals of Mathematical Statistics, v. 21, no. 4, p. 557-569, accessed October 2019 at https://doi.org/ 10.1214/aoms/1177729751.

Cook, R.D., 1977, Detection of influential observations in linear regression: Technometrics, v. 19, no. 1, p. 15-18. [Also available at https://www.jstor.org/stable/1268249.]

Duan, N., 1983, Smearing estimate-A nonparametric retransformation method: Journal of the American Statistical Association, v. 78, no. 383, p. 605-610. [Also available at https://doi.org/10.1080/01621459.1983.10478017.]

Fishman, M.J., and Friedman, L.C., 1989, Methods for determination of inorganic substances in water and fluvial sediments ( 3 d ed.): U.S. Geological Survey Techniques of Water-Resources Investigations, book 5, chap. A1, 545 p. [Also available at https://doi.org/10.3133/twri05A1.]

Foster, G.M., and Graham, J.L., 2016, Logistic and linear regression model documentation for statistical relations between continuous real-time and discrete water-quality constituents in the Kansas River, Kansas, July 2012 through June 2015: U.S. Geological Survey OpenFile Report 2016-1040, 27 p., accessed July 2020 at https://doi.org/10.3133/ofr20161040.

Fry, J.A., Xian, G.S., Jin, S., Dewitz, J., Homer, C., Yang, L., Barnes, C.A., Herold, N., and Wickham, J.D., 2011, Completion of the 2006 National Land Cover Database for the conterminous United States: Photogrammetric Engineering and Remote Sensing, v. 77, no. 9, p. 858-864.

Graham, J.L., Foster, G.M., Williams, T.J., Mahoney, M.D., May, M.R., and Loftin, K.A., 2018, Water-quality conditions with an emphasis on cyanobacteria and associated toxins and taste-and-odor compounds in the Kansas River, Kansas, July 2012 through September 2016: U.S. Geological Survey Scientific Investigations Report 2018-5089, 55 p. [Also available at https://doi.org/10.3133/ sir20185089.]

Graham, J.L., Ziegler, A.C., Loving, B.L., and Loftin, K.A., 2012, Fate and transport of cyanobacteria and associated toxins and taste-and-odor compounds from upstream reservoir releases in the Kansas River, Kansas, September and October 2011: U.S. Geological Survey Scientific Investigations Report 2012-5129, 65 p. [Also available at https://doi.org/10.3133/sir20125129.]
Guy, H.P., 1969, Laboratory theory and methods for sediment analysis: U.S. Geological Survey Techniques of WaterResources Investigations, book 5, chap. C1, 58 p. [Also available at https://doi.org/10.3133/twri05C1.]

Hald, A., 1949, Maximum likelihood estimation of the parameters of a normal distribution which is truncated at a known point: Scandinavian Actuarial Journal, v. 1949, no. 1, p. 119-134. [Also available at https://doi.org/10.1080/ 03461238.1949.10419767.]

Helsel, D.R., 2012, Statistics for censored environmental data using Minitab and R: New York, John Wiley \& Sons, 344 p.

Helsel, D.R., Hirsch, R.M., Ryberg, K.R., Archfield, S.A., and Gilroy, E.J., 2020, Statistical methods in water resources: U.S. Geological Survey Techniques and Methods, book 4, chap. A3, 458 p. [Also available at https://doi.org/10.3133/t m4a3.] [Supersedes USGS Techniques of Water-Resources Investigations, book 4, chap. A3, ver. 1.1.]

Hem, J.D., 1992, Study and interpretation of the chemical characteristics of natural water: U.S. Geological Survey Water-Supply Paper 2254. 3rd ed., 264 p. [Also available at https://doi.org/10.3133/wsp2254.]

Kansas Department of Health and Environment, 2011, KansasLower Republican Basin total maximum daily load: Kansas Department of Health and Environment web page, accessed April 2012 at https://www.kdheks.gov/tmdl/krtmdl.htm.

Knowlton, M.F., 1984, Flow-through microcuvette for fluorometric determination of chlorophyll: Journal of the American Water Resources Association, v. 20, no. 5, p. 795-799. [Also available at https://doi.org/10.1111/ j.1752-1688.1984.tb04763.x.]

Marquardt, D.W., 1970, Generalized inverses, ridge regression, biased linear estimation, and nonlinear estimation: Technometrics, v. 12, no. 3, p. 591-612. [Also available at https://doi.org/10.2307/1267205.]

McKelvey, R.D., and Zavoina, W., 1975, A statistical model for the analysis of ordinal level dependent variables: The Journal of Mathematical Sociology, v. 4, no. 1, p. 103-120. [Also available at https://doi.org/10.1080/0022250X.19 75.9989847.]

Mueller, D.K., Schertz, T.L., Martin, J.D., and Sandstrom, M.W., 2015, Design, analysis, and interpretation of field quality-control data for water-sampling projects: U.S. Geological Survey Techniques and Methods, book 4, chap. C4, 54 p., accessed July 2020 at https://doi.org/10.3133/t m4C4. 
Myers, D.N., Stoeckel, D.M., Bushon, R.N., Francy, D.S., and Brady A.M.G., 2014, Chapter A7.1, Fecal Indicator Bacteria: U.S. Geological Survey Techniques of WaterResources Investigations, book 9, chap. A7.1, [Also available at https://doi.org/10.3133/twri09A7.1.]

O'brien, R.M., 2007, A caution regarding rules of thumb of variance inflation factors: Quality \& Quantity, v. 41, no. 5, p. 673-690, accessed September 2020. https://doi.org/ 10.1007/s11135-006-9018-6.

Pellerin, B.A., Bergamaschi, B.A., Downing, B.D., Saraceno, J.F., Garrett, J.D., and Olsen, L.D., 2013, Optical techniques for the determination of nitrate in environmental watersGuidelines for instrument selection, operation, deployment, maintenance, quality assurance, and data reporting: U.S. Geological Survey Techniques and Methods, book 1, chap. D5, 37 p. [Also available at https://doi.org/10.3133/tm1D5.]

$\mathrm{R}$ Core Team, 2020, R-A language and environment for statistical computing, version 4.0.3: Vienna, Austria, R Foundation for Statistical Computing, accessed December 2020 at https://www.R-project.org/.

Rasmussen, P.P., Gray, J.R., Glysson, G.D., and Ziegler, A.C., 2009, Guidelines and procedures for computing time-series suspended-sediment concentrations and loads from in-stream turbidity sensor and streamflow data: U.S. Geological Survey Techniques and Methods, book 3, chap. C4, 53 p. [Also available at https://doi.org/10.3133/tm3C4.]

Rasmussen, T.J., Ziegler, A.C., and Rasmussen, P.P., 2005, Estimation of constituent concentrations, densities, loads, and yields in lower Kansas River, northeast Kansas, using regression models and continuous water-quality monitoring, January 2000 through December 2003: U.S. Geological Survey Scientific Investigations Report 2005-5165, 117 p. [Also available at https://doi.org/10.3133/sir20055165.]

Sartory, D.P., and Grobbelaar, J.U., 1984, Extraction of chlorophyll $a$ from freshwater phytoplankton for spectrophotometric analysis: Hydrobiologia, v. 114, no. 3, p. 177-187. [Also available at https://doi.org/10.1007/BF00031869.]

Sauer, V.B., and Turnipseed, D.P., 2010, Stage measurement at gaging stations: U.S. Geological Survey Techniques and Methods, book 3, chap. A7, 45 p., accessed July 2020 at https://doi.org/10.3133/tm3A7.

Tobin, J., 1958, Estimation of relationships for limited dependent variables: Econometrica, v. 26, no. 1, p. 24-36. [Also available at https://doi.org/10.2307/1907382.]

Turnipseed, D.P., and Sauer, V.B., 2010, Discharge measurements at gaging stations: U.S. Geological Survey Techniques and Methods, book 3, chap. A8, 87 p., accessed July 2020 at https://doi.org/10.3133/tm3A8.
U.S. Army Corps of Engineers, 2017, Kansas City district lakes: U.S. Army Corps of Engineers, web page, accessed September 16, 2017, at https://www.nwk.usace.army.mil/ Locations/.

U.S. Geological Survey, 2006, Collection of water samples (ver. 2.0, September 2006): U.S. Geological Survey Techniques of Water-Resources Investigations, book 9, chap. A4, 166 p. [Also available at https://doi.org/10.3133/ twri09A4.]

U.S. Geological Survey, 2008, Field measurements, (edited by Wilde, F.D.): U.S. Geological Survey Techniques of Water-Resources Investigations, book 9; chap A6, [variously paged], accessed July 2020 at https://doi.org/10.3133/ twri09A6.

U.S. Geological Survey, 2016, Policy and guidance for approval of surrogate regression models for computation of time series suspended-sediment concentrations and loads: U.S. Geological Survey, Office of Water Quality Technical Memorandum 2016.10, 40 p., accessed December 2020 at https://water.usgs.gov/admin/memo/QW/qw2016.10.pdf.

U.S. Geological Survey, 2017, Procedures for processing, approving, publishing, and auditing time-series records for water data: U.S. Geological Survey, Office of Water Quality Technical Memorandum 2017.07, accessed December 2020 at https:/water.usgs.gov/admin/memo/QW/qw2017.07.pdf.

U.S. Geological Survey, 2020, USGS water data for the Nation: U.S. Geological Survey National Water Information System database, accessed April 2020 at https://doi.org/ 10.5066/F7P55KJN.

Vatcheva, K.P., Lee, M., McCormick, J.B., and Rahbar, M.H., 2016, Multicollinearity in regression analyses conducted in epidemiologic studies: Epidemiology, v. 6, no. 2, 9 p., accessed September 2020 at https://doi.org/10.4172/21611165.1000227.

Wagner, R.J., Boulger, R.W., Jr., Oblinger, C.J., and Smith, B.A., 2006, Guidelines and standard procedures for continuous water-quality monitors-Station operation, record computation, and data reporting: U.S. Geological Survey Techniques and Methods, book 1, chap. D3, 51 p. plus 8 attachments. [Also available at https://doi.org/10.3133/t m1D3.] [Supersedes USGS Water-Resources Investigations Report 2000-4252.]

Incorporated, Y.S.I., 2012, EXO water quality field sensorsFeatures, specifications, and comparability to YSI 6-Series sensors: YSI Incorporated, revision B, 14 p., accessed July 2020 at https://www.exowater.com/media/pdfs/EXO6Series-Sensor-Comparison.pdf.

Zar, J.H., 1999, Biostatistical analysis (4th ed.): New Jersey, Prentice-Hall Inc., 663 p. 


\section{Appendixes 1-32}

Appendixes 1-32 contain the model archive summaries for the regression models that were updated or developed at the Kansas River at Wamego (U.S. Geological Survey site 06887500 ) and De Soto (U.S. Geological Survey site 06892350) sites in this report. Each model archive summary documents model-specific information including, but not limited to, site location, methodology, regression-estimation method, percentage of censored data, data identified as outliers, model form, previously published regression models, model diagnostic statistics and plots, and the model calibration dataset. Appendixes 1-14 contain model information for total dissolved solids, major ions, and hardness; appendixes 15-22 contain model information for nutrients (including nitrate plus nitrite, total nitrogen, and total phosphorus) and chlorophyll $a$; appendixes 23-26 contain model information for total suspended solids and suspended-sediment concentrations; and appendixes 27-32 contain model information for fecal indicator bacteria, including Escherichia coli, fecal coliform, and enterococci bacteria. All appendixes are available for download at https://doi.org/10.3133/ofr20211018. A list of the appendix titles is included for the convenience of the reader:

- Appendix 1. Model Archival Summary for Total Dissolved Solids Concentration at U.S. Geological Survey Site 06887500, Kansas River at Wamego, Kansas, during July 2012 through September 2019

- Appendix 2. Model Archival Summary for Total Dissolved Solids Concentration at U.S. Geological Survey Site 06892350, Kansas River at De Soto, Kansas, during July 2012 through September 2019

- Appendix 3. Model Archival Summary for Calcium Concentration at U.S. Geological Survey Site 06887500, Kansas River at Wamego, Kansas, during July 2012 through September 2019

- Appendix 4. Model Archival Summary for Calcium Concentration at U.S. Geological Survey Site 06892350, Kansas River at De Soto, Kansas, during July 2012 through September 2019

- Appendix 5. Model Archival Summary for Magnesium Concentration at U.S. Geological Survey Site 06887500, Kansas River at Wamego, Kansas, during July 2012 through September 2019

- Appendix 6. Model Archival Summary for Magnesium Concentration at U.S. Geological Survey Site 06892350, Kansas River at De Soto, Kansas, during July 2012 through September 2019
- Appendix 7. Model Archival Summary for Sodium Concentration at U.S. Geological Survey Site 06887500, Kansas River at Wamego, Kansas, during July 2012 through September 2019

- Appendix 8. Model Archival Summary for Sodium Concentration at U.S. Geological Survey Site 06892350, Kansas River at De Soto, Kansas, during July 2012 through September 2019

- Appendix 9. Model Archival Summary for Sulfate Concentration at U.S. Geological Survey Site 06887500, Kansas River at Wamego, Kansas, during July 2012 through September 2019

- Appendix 10. Model Archival Summary for Sulfate Concentration at U.S. Geological Survey Site 06892350, Kansas River at De Soto, Kansas, during July 2012 through September 2019

- Appendix 11. Model Archival Summary for Chloride Concentration at U.S. Geological Survey Site 06887500, Kansas River at Wamego, Kansas, during July 2012 through September 2019

- Appendix 12. Model Archival Summary for Chloride Concentration at U.S. Geological Survey Site 06892350, Kansas River at De Soto, Kansas, during July 2012 through September 2019

- Appendix 13. Model Archival Summary for Hardness Concentration at U.S. Geological Survey Site 06887500, Kansas River at Wamego, Kansas, during July 2012 through September 2019

- Appendix 14. Model Archival Summary for Hardness Concentration at U.S. Geological Survey Site 06892350, Kansas River at De Soto, Kansas, during July 2012 through September 2019

- Appendix 15. Model Archival Summary for Nitrate plus Nitrite Concentration at U.S. Geological Survey Site 06887500, Kansas River at Wamego, Kansas, during June 2014 through September 2019

- Appendix 16. Model Archival Summary for Nitrate plus Nitrite Concentration at U.S. Geological Survey Site 06892350, Kansas River at De Soto, Kansas, during June 2013 through September 2019

- Appendix 17. Model Archival Summary for Total Nitrogen Concentration at U.S. Geological Survey Site 06887500, Kansas River at Wamego, Kansas, during June 2014 through September 2019 
- Appendix 18. Model Archival Summary for Total Nitrogen Concentration at U.S. Geological Survey Site 06892350, Kansas River at De Soto, Kansas, during June 2014 through September 2019

- Appendix 19. Model Archival Summary for Total Phosphorus Concentration at U.S. Geological Survey Site 06887500, Kansas River at Wamego, Kansas, during September 2013 through September 2019

- Appendix 20. Model Archival Summary for Total Phosphorus Concentration at U.S. Geological Survey Site 06892350, Kansas River at De Soto, Kansas, during September 2013 through September 2019

- Appendix 21. Model Archival Summary for Chlorophyll $a$ Concentration at U.S. Geological Survey Site 06887500, Kansas River at Wamego, Kansas, during June 2014 through September 2019

- Appendix 22. Model Archival Summary for Chlorophyll $a$ Concentration at U.S. Geological Survey Site 06892350, Kansas River at De Soto, Kansas, during June 2014 through September 2019

- Appendix 23. Model Archival Summary for Total Suspended Solids Concentration at U.S. Geological Survey Site 06887500, Kansas River at Wamego, Kansas, during September 2013 through September 2019

- Appendix 24. Model Archival Summary for Total Suspended Solids Concentration at U.S. Geological Survey Site 06892350, Kansas River at De Soto, Kansas, during September 2013 through September 2019

- Appendix 25. Model Archival Summary for Suspended-Sediment Concentration at U.S. Geological Survey Site 06887500, Kansas River at Wamego, Kansas, during September 2013 through September 2019
- Appendix 26. Model Archival Summary for Suspended-Sediment Concentration at U.S. Geological Survey Site 06892350, Kansas River at De Soto, Kansas, during September 2013 through September 2019

- Appendix 27. Model Archival Summary for Escherichia coli Bacteria Density at U.S. Geological Survey Site 06887500, Kansas River at Wamego, Kansas, during September 2013 through September 2019

- Appendix 28. Model Archival Summary for Escherichia coli Bacteria Density at U.S. Geological Survey Site 06892350, Kansas River at De Soto, Kansas, during September 2013 through September 2019

- Appendix 29. Model Archival Summary for Fecal Coliform Bacteria Density at U.S. Geological Survey Site 06887500, Kansas River at Wamego, Kansas, during October 2013 through September 2019

- Appendix 30. Model Archival Summary for Fecal Coliform Bacteria Density at U.S. Geological Survey Site 06892350, Kansas River at De Soto, Kansas, during October 2013 through September 2019

- Appendix 31. Model Archival Summary for Enterococci Bacteria Density at U.S. Geological Survey Site 06887500, Kansas River at Wamego, Kansas, during September 2013 through September 2019

- Appendix 32. Model Archival Summary for Enterococci Bacteria Density at U.S. Geological Survey Site 06892350, Kansas River at De Soto, Kansas, during September 2013 through September 2019 
For more information about this publication, contact:

Director, USGS Kansas Water Science Center

1217 Biltmore Drive

Lawrence, KS 66049

785-842-9909

For additional information, visit: https://www.usgs.gov/centers/kswsc

Publishing support provided by the

Rolla Publishing Service Center 


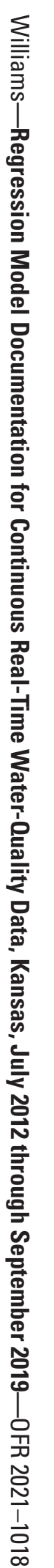

